University of California, Hastings College of the Law

UC Hastings Scholarship Repository

Faculty Scholarship

2020

\title{
Coequal Federalism and Federal-State Agencies
}

Dave Owen

UC Hastings College of the Law, owendave@uchastings.edu

Hannah Jacobs Wiseman

Follow this and additional works at: https://repository.uchastings.edu/faculty_scholarship

\section{Recommended Citation}

Dave Owen and Hannah Jacobs Wiseman, Coequal Federalism and Federal-State Agencies, 55 Ga. L. Rev. 287 (2020).

Available at: https://repository.uchastings.edu/faculty_scholarship/1794

This Article is brought to you for free and open access by UC Hastings Scholarship Repository. It has been accepted for inclusion in Faculty Scholarship by an authorized administrator of UC Hastings Scholarship Repository. For more information, please contact wangangela@uchastings.edu. 


\title{
COEQUAL FEDERALISM AND FEDERAL- STATE AGENCIES
}

\author{
Dave Owen* \& Hannah J. Wiseman ${ }^{\dagger}$
}

Dividing authority between the federal government and the states is central to the theory and practice of federalism. Division is the defining feature of dual federalism, which dominates the U.S. Supreme Court's federalism jurisprudence. Recent academic theories of federalism emphasize overlap and interaction but still assume that federal and state actors will work within separate institutions. Each approach can be problematic, yet assumptions of separation remain the bedrock of federalism. This Article discusses a different form of federalism: coequal federalism. Under coequal federalism, federal- and state-appointed officials collaborate within a single agency that makes decisions binding on the federal government and the states. This form of federalism exists only within obscure niches of American governance, and it is largely absent from theoretical discussions. We argue that it should receive more extensive attention and use. We also explain how coequal federalism can function in practice, when it will offer a desirable alternative to more traditional approaches, and why it is constitutional.

\footnotetext{
* Harry D. Sunderland Professor of Real Property Law, University of California, Hastings College of Law. The authors thank Todd Aagaard, Hadar Aviram, Dan Farber, Dorit Reiss, Chimene Keitner, Alexandra Klass, Dave Markell, Zachary Price, Erin Ryan, and David Takacs for helpful comments on drafts of this Article.

† Professor of Law; Professor and Wilson Faculty Fellow, College of Earth and Mineral Sciences; Institutes of Energy and the Environment Co-funded Faculty, Penn State University, Penn State Law.
} 


\section{TABLE OF CONTENTS}

I. INTRODUCTION 290

II. A BLUEPRINT FOR JOINT FEDERAL-STATE GOVERNANCE.. 298

A. THE GENERAL STRUCTURE OF FEDERAL-STATE

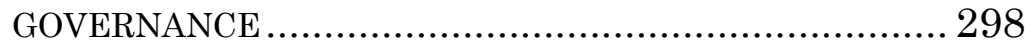

B. THE MECHANICS OF FEDERAL-STATE GOVERNANCE .. 299

1. Participation ............................................ 299

2. Legislative Creation ...................................... 300

3. Membership............................................... 301

4. Staffing and Funding.................................. 304

5. Powers .............................................................. 304

6. Judicial Review ......................................... 305

III. A NORMATIVE JUSTIFICATION FOR JOINT FEDERAL-STATE

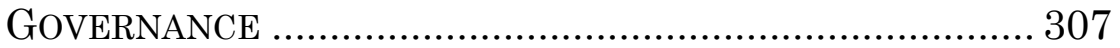

A. DIVIDE AND SEPARATE....................................... 307

B. THE CHALLENGES OF DIVISION ........................... 310

C. OVERLAP AND COORDINATE ................................. 313

D. THE CHALLENGES OF OVERLAP............................. 318

E. THE ADVANTAGES OF JOINT GOVERNANCE.............. 320

F. THE CIRCUMSTANCES FOR JOINT GOVERNANCE ........ 323

1. Siting Transmission Lines for Electricity

Generation .................................................. 324

2. Interstate Water Quantity and Quality ........... 326

IV. The CONSTITUTIONALiTy OF JOINT FEDERAL-STATE

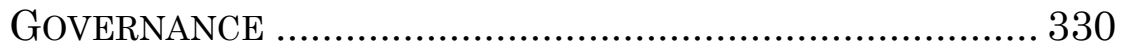

A. DORMANT COMMERCE CLAUSE ........................... 334

B. ANTI-COMMANDEERING ................................... 337

C. DELEGATION, APPOINTMENT, AND REMOVAL ............ 340

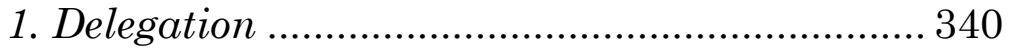

2. Appointment.............................................. 344 
3. Removal ...................................................... 346

D. ARGUMENTS FROM CONSTITUTIONAL STRUCTURE AND

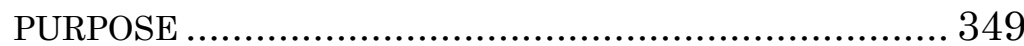

1. Diminishing the States? ............................... 350

2. Diminishing the People? ................................ 353

V. ConCLUSION........................................................... 358 


\section{INTRODUCTION}

Dividing authority between the federal government and states presents, in the U.S. Supreme Court's apt words, "perhaps our oldest question of constitutional law." As both federal and state governments have grown, that question also has become centrally important to administrative law. ${ }^{2}$ In fields ranging from health care to energy, deciding how to allocate power among federal and state agencies is a pervasive and exceedingly contentious challenge. ${ }^{3}$

Broadly speaking, the traditional responses to that challenge, both in practice and in the literature, fit into two categories of federalism. One approach-dual federalism-assigns exclusive authority to federal or state agencies. ${ }^{4}$ The other approach gives federal and state agencies overlapping authority, which they may exercise either in coordination-an approach often called

\footnotetext{
1 New York v. United States, 505 U.S. 144, 149 (1992). For one of the earliest instantiations of this challenge, see McCulloch v. Maryland, 17 U.S. 316, 326 (1819), which observed that "[t]he people of the United States have seen fit to divide sovereignty, and to establish a complex system," and that, within this system, "it was easy to foresee that question must arise between" the powers conferred on state governments and the national government. A related and intriguing question-which, for reasons of brevity, this Article does not address-is whether and how local governments might become involved in joint administrative governance that also involves the federal and state governments.

2 See, e.g., Gillian E. Metzger, Administrative Law as the New Federalism, 57 DukE L.J. 2023, 2025-28 (2008) (discussing the Court's invocation of federalism questions when addressing Chevron deference to federal agencies' interpretation of statutes); Frank R. Strong, The Future of Federalism in the United States, 22 TEx. L. REV. 255, 275 (1944) (providing early recognition of "administrative federalism" and its "significant application in governmental practice").

3 See, e.g., Fed. Energy Regulatory Comm'n v. Elec. Power Supply Ass'n, 136 S. Ct. 760, 767 (2016) (considering the boundaries of federal and state authority over energy pricing); Nat'l Fed'n of Indep. Bus. v. Sebelius, 567 U.S. 519, 532-34 (2012) (considering the boundaries of federal authority over healthcare regulation).

${ }_{4}^{4}$ See Robert A. Schapiro, Toward a Theory of Interactive Federalism, 91 IowA L. REV. 243, 246 (2005) ("Dual federalism refers to the concept that the state and national governments enjoy exclusive and non-overlapping spheres of authority."). Although dual federalism has been declared "dead" by many scholars, it stubbornly remains in modern legal doctrine. See, e.g., id. (proclaiming that "[d]ual federalism is dead"). For continued line-drawing between state and federal authority, see Murphy v. NCAA, 138 S. Ct. 1461, 1476 (2018), which struck down a federal law that prohibited states from authorizing sports gambling because Congress lacks "the power to issue direct orders to the governments of the States."
} 
cooperative federalism - or independently. ${ }^{5}$ Both independent and overlapping authority systems are common and have been extensively theorized. ${ }^{6}$ Both have achieved some success, but they have also created deep-seated problems. Dual federalism offers simplicity and preserves some values associated with federal or state primacy, but it also often subordinates important national or state interests. ${ }^{7}$ Drawing sensible lines between federal and state zones of authority can be extraordinarily difficult, particularly in a nation where complex policy issues rarely align neatly with one level of governance. ${ }^{8}$ Overlapping governance only partially

${ }_{5}^{5}$ See Schapiro, supra note 4, at 250 (noting that in cooperative federalism, "[t]he state and federal governments do not enjoy mutually exclusive and non-overlapping areas of power"). The benefits and challenges of multiple-federal-agency management have received extensive attention in recent literature, but our analysis leaves those questions largely to the side. See, e.g., Daphna Renan, Pooling Powers, 115 Colum. L. REV. 211, 213 (2015) (discussing how agencies can pool powers "to combine one agency's expertise with legal authority allocated to another"); Jody Freeman \& Jim Rossi, Agency Coordination in Shared Regulatory Space, 125 HARV. L. REV. 1131, 1138 (2012) (commenting on the challenges and benefits of federal jurisdictional areas in which two or more agencies exercise regulatory control).

${ }^{6}$ The federalism canon is massive, but some of the prominent explorations, critiques, praise for, and theories of dual and cooperative federalism include ROBERT A. SCHAPIRO, Polyphonic Federalism: TOWARD the Protection of Fundamental Rights 55 (2009) (describing "dualist" federalism); William W. Buzbee, Asymmetrical Regulation: Risk, Preemption, and the Floor/Ceiling Distinction, 82 N.Y.U. L. REV. 1547, 1550 (2007) (describing the tension between traditional dual federalism and the emergence of overlapping governance structures, known as "cooperative" or "delegated program" federalism); Caleb Nelson, Preemption, 86 VA. L. REV. 225, 231-32 (2000) (critiquing judicial and theoretical approaches to preemption theory); and Edward S. Corwin, The Passing of Dual Federalism, 36 VA. L. REV. 1, 3-4 (1950) (arguing that dual federalism no longer accurately describes governance regimes).

${ }^{7}$ For a discussion of how dual sovereignty still dominates legal doctrine, see, for example, ERIN RYAN, FEDERALISM AND THE TUG OF WAR Within 3-4 (2011). A recent example of the subordination of state interests is the National Highway Traffic Safety Administration's (NHTSA's) and Environmental Protection Agency's (EPA's) regulation that withdrew states' authority to regulate greenhouse gas emissions from cars. See Complaint for Declaratory and Injunctive Relief at 4, California v. Chao, No. 1:19-cv-02826 (D.D.C. Sept. 20, 2019) (showing twenty-three states' challenge to the NHTSA and EPA regulation).

8 See, e.g., Matthew C. Waxman, National Security Federalism in the Age of Terror, 64 STAN. L. REV. 289, 294 (2012) (exploring the complex relationships among federal agencies and between federal agencies and local government actors in the national security context); Cristina M. Rodríguez, The Significance of the Local in Immigration Regulation, $106 \mathrm{MICH}$. L. REV. 567, 571 (2008) (arguing that the "federal government, the states, and localities form part of an integrated regulatory structure" and that immigration federalism scholarship ignores this complexity). 
resolves these issues and presents its own challenges. While overlap brings more interests into decisionmaking processes and avoids stripping one governmental level of authority, it can result in confusion, delay, and conflicting decisions. ${ }^{9}$

Many potential examples of these challenges exist, but we start with just one. A successful energy and climate policy likely will depend on developing new electric transmission lines, which would deliver electricity_largely renewable-from the Great Plains and the southwest to population centers further east and west. ${ }^{10} \mathrm{~A}$ dual federalism approach, in which either the federal government or states have exclusive authority, would not be ideal for siting these lines because it would ignore either state interests in managing major land uses or federal interests in managing an international electrical grid. Cooperative federalism also would not be ideal because it envisions separate state-by-state decisionmaking, and transmission lines would have little value if adjacent states failed to ensure that transmission aligned at state borders. A system of uncoordinated overlap also would not make sense because it would involve serial, and potentially conflicting, approval processes for each transmission line. Consequently, here, and in other policy realms with similar characteristics, a different governance approach is needed. ${ }^{11}$

Because of the limitations of cooperative federalism and independent approaches, this Article discusses a third, distinct form of federalism: coequal federal-state authority exercised through joint agencies. Rather than relegating governance to one

9 See, e.g., Daniel P. Selmi, Themes in the Evolution of the State Environmental Policy Acts, 38 URB. LAW. 949, 962-63 (2006) (noting "consistent criticism" of the need to duplicate environmental analyses under state and federal law and that, although states have attempted to coordinate review processes to avoid duplication, "these efforts toward administrative efficiency often fail"); Hannah J. Wiseman, Delegation and Dysfunction, 35 YALE J. ON REG. 233, 240-45 (2018) (describing agency costs associated with cooperative federalism, including principal-agent problems). Overlapping authority can also result in inaction when one entity assumes that another entity is addressing the problem. See William W. Buzbee, Recognizing the Regulatory Commons: A Theory of Regulatory Gaps, 89 IOWA L. REV. 1, 6-14 (2003) (noting that when multiple entities have only partial jurisdiction over a widespread problem, a "regulatory commons" can emerge in which there is "political underinvestment" in the problem).

10 See Alexandra B. Klass, Future-Proofing Energy Transport Law, 94 WASH. U. L. REV. 827,847 (2017) ("New, long-distance electric transmission lines are critical to expand the use of renewable energy for electricity and to reduce reliance on fossil fuels.”).

${ }^{11}$ See infra Section III.F.1. 
level or envisioning separate and semi-coordinated federal and state decisionmaking, this approach involves joint federal and state action within a single administrative agency. This federalstate agency would be created-and its responsibilities definedby federal and state legislation, with at least one state participating. A multi-member commission with federal and state appointees would oversee the agency's affairs, with that commission supported by a dedicated agency staff. Participation in the agency would be voluntary: neither the states nor the federal government could order one another to join, and either could withdraw from participation. But so long as the agency continued to be active, it could issue rules and orders that bound federal and participating-state officials and private actors.

Versions of coequal federalism exist, but only in obscure niches of American governance-none of which have demonstrated the full potential of this governance form. ${ }^{12}$ The Compact Clause of the U.S. Constitution authorizes Congress to approve interstate compacts, and some interstate compacts create agencies, a few of which have federal participation. ${ }^{13}$ But only a few of these entities currently operate-they handle tasks like governing water management in a few interstate rivers ${ }^{14}$ and managing the Reagan

\footnotetext{
12 See infra notes 171-189 and accompanying text (explaining why interstate river basin management poses challenges for joint federal-state governance).

${ }_{13}$ U.S. Const. art. I, § 10, cl. 3 ("No State shall, without the Consent of Congress ... enter into any agreement or Compact with another State ....").

14 See, e.g., About DRBC, DEL. RIVER BASIN COMMISSION, https://www.state.nj.us/drbc/about/ (last visited Oct. 10, 2020) (explaining the history of the Delaware River Basin Commission and its role in managing, protecting, and improving the basin's water resources); About Us, SUSQUEHANNA RIVER BASIN COMMISSION, https://www.srbc.net/about/about-us/ (last visited Oct. 10, 2020) (describing the history, structure, and goals of the Susquehanna River Basin Commission); UPPER COLO. RIVER COMMISsion, http://www.ucrcommission.com/ (last visited Oct. 10, 2020) (describing the organization, history, and responsibilities of the Upper Colorado River Commission); About Us, OHIO RIVER VALLEY WATER SANITATION COMMISSION, http://www.orsanco.org/about-us/ (last visited Oct. 10, 2020) (describing the Ohio River Valley Water Sanitation Commission's role in improving the water quality of the Ohio River and its tributaries); $c f$. New Jersey v. New York, 347 U.S. 995, 996-1001 (1954) (addressing a water dispute among four states and New York City, and determining water allocations); 1954 U.S. Supreme Court Decree, DEL. RIVER BASIN COMMISSION, https://www.nj.gov/drbc/programs/flow/decree.html (last visited Oct. 10, 2020) (describing legislation in which the four states that were parties to the suit and the United States formed a compact to govern water allocation).
} 
National and Dulles airports ${ }^{15}$ —and none of them are particularly prominent. Aside from these limited examples, giving federal-state agencies significant authority to regulate and bind the federal government and participating states would be new to American governance. ${ }^{16}$

Discussion of coequal federalism is largely new to the literature. $^{17}$ Even the dynamic federalism ${ }^{18}$ and nationalist

15 About the Airports Authority, Metropolitan Wash. Airports Authority, https://www.mwaa.com/about/about-airports-authority (last visited Oct. 10, 2020) (discussing the mission and governance of the Airports Authority).

16 A somewhat analogous arrangement is common in law enforcement, where federal agents often form joint task forces with their state or local counterparts. But these arrangements are typically ad hoc, temporary, and involve state or local officials who voluntarily serve within a federal command structure. See JEROME P. BJELOPERA \& KRISTIN Finklea, Cong. Research Serv., R43583, Domestic Federal LAW Enforcement COORDINATION: THROUGH THE LENS OF THE SOUTHWEST BORDER 2-6 (2014) (documenting numerous federal-state-local "investigative operations" through voluntary task forces and information-sharing "fusion centers" to combat drug trafficking and other crimes). The combination of joint structures and secrecy also can create transparency problems that might not occur in other realms. See also Susan N. Herman, Collapsing Spheres: Joint Terrorism Task Forces, Federalism, and the War on Terror, 41 WiLlameTte L. REV. 941, 943 (2005) (explaining how joint task forces can disrupt local government and shift policymaking authority to the Executive Branch "where accountability and transparency are minimized").

17 But see Martha Derthick, Between State and Nation: Regional Organizations of THE UNited StATES 49-52, 66-67 (1974) (discussing the challenges the Delaware River Basin Authority faced in its early years).

18 The "dynamic federalism" literature explores, and often supports, forms of shared federal-state authority, but not formal, joint authority. See David E. Adelman \& Kirsten H. Engel, Adaptive Federalism: The Case Against Reallocating Environmental Regulatory Authority, 92 MinN. L. REV. 1796, 1799 (2008) (drawing on dynamic federalism legal scholarship and asserting that "the initiative to address environmental problems will originate from more than one level of government based upon a variety of political, socioeconomic, and environmental factors . . .."); Ann E. Carlson, Iterative Federalism and Climate Change, 103 Nw. U. L. REV. 1097, 1100 (2009) (focusing on "schemes of federalism where federal law consciously designates a particular and distinct state or group of states to regulate and relies on that regulatory arrangement to enhance compliance with federal standards"); Kirsten H. Engel, Harnessing the Benefits of Dynamic Federalism in Environmental Law, 56 EMORY L.J. 159, 161 (2006) (rejecting the assumption that regulatory authority "should be allocated to one or the other level of government with minimal overlap”); Erin Ryan, Negotiating Federalism, 52 B.C. L. REV. 1, 13-14 (2011) (describing how state and federal actors often bargain above the formal cooperative federalism framework); Schapiro, supra note 4, at 285 (advocating for a "polyphonic conception" of federalism "characterized by the existence of multiple, independent sources of political authority"). 
federalism literatures, ${ }^{19}$ which move the federalism debate far beyond the confines of traditional dual or even cooperative federalism, lack an account of coequal federal-state governance.

This Article constructs that account. It explains what coequal federalism is and why it deserves more theoretical exploration and real-world use. The primary arguments for coequal federalism are straightforward: it limits the line-drawing and subordination problems associated with federalism theories grounded in separation of power, and it reduces the coordination challenges that arise from overlapping federalism. More generally, coequal federalism addresses a problem largely glossed over by recent federalism theory, which often celebrates federal-state overlap without explaining the governance structures that will generate successful collaborations instead of disorganization, conflict, and delay. Joint federal-state administration would not make sense in all circumstances, so we frame conditions under which it could be most effective. ${ }^{20}$ Forming a new joint federal-state agency also could be politically difficult, particularly at a time when state and federal officials often seem to relish separation and disagreement. ${ }^{21}$ But even with these caveats, coequal federalism deserves more attention.

\footnotetext{
19 See, e.g., Heather K. Gerken, Federalism as the New Nationalism: An Overview, 123 YALE L.J. 1889, 1890 (2014) (describing how federalism is now "deeply nationalist in character"); Abbe R. Gluck, Our [National] Federalism, 123 YALE L.J. 1996, 2002 (2014) (developing the account of "Congress as our primary source of federalism" through federal mandates that deeply involve the states in their implementation). The dynamic federalism and nationalist federalism literatures overlap. See Jessica Bulman-Pozen \& Heather K. Gerken, Uncooperative Federalism, 118 YALE L.J. 1256, 1271-84 (2009) (discussing how cooperative federalism systems can facilitate productive disagreement when states refuse to comply with federal directives or challenge them in other ways); Abbe R. Gluck, Intrastatutory Federalism and Statutory Interpretation: State Implementation of Federal Law in Health Reform and Beyond, 121 YALE L.J. 534, 585-89 (2011) (providing examples that defy traditional federalism structures); Cristina M. Rodríguez, Negotiating Conflict Through Federalism: Institutional and Popular Perspectives, 123 YAlE L.J. 2094, 2097 (2014) (discussing the benefits of shared governance through cooperative federalism).

${ }^{20}$ See infra Section III.F.

21 See Margaret H. Lemos \& Ernest A. Young, State Public-Law Litigation in an Age of Polarization, 97 TEX. L. REV. 43, 47 (2018) (noting that state lawsuits against the federal government have "grown in volume and prominence"); Elbert Lin, States Suing the Federal Government: Protecting Liberty or Playing Politics?, 52 U. RICH. L. REV. 633, 634-46 (2018) (describing state-federal legal clashes).
} 
Nevertheless, even in contexts where it otherwise makes policy sense, joint federal-state governance may generate legal challenges, some grounded in the U.S. Constitution. Creating a joint federal-state agency would generate questions about dormant Commerce Clause authority, ${ }^{22}$ the delegation doctrine, ${ }^{23}$ the vesting of executive authority in the President, ${ }^{24}$ the anticommandeering doctrine, ${ }^{25}$ and appointment and removal authority, ${ }^{26}$ as well as questions of state constitutional law. ${ }^{27}$ Some of these issues are relatively straightforward, but some are thorny. ${ }^{28}$ More generally, joint state-federal governance might seem at odds with broader constitutional principles. The U.S. Supreme Court has stated that "[t]he Constitution requires a distinction between what is truly national and what is truly local," 29 and such separations ostensibly preserve the autonomy of the states and protect the public from overly powerful governance entities. ${ }^{30}$ This concept, if taken far enough, could preclude the creation of a joint governance entity and may call into question the few federal-state entities that already operate. ${ }^{31}$ Federal-state entities were formed well before the resurgences of formalism and dual federalism that define much of the modern Court's

22 See infra Section IV.A.

${ }^{23}$ See infra Section IV.c.

${ }^{24}$ U.S. Const. art. II, $\S 1$ ("The executive Power shall be vested in a President of the United States of America."); see id. art. II, § 3 ("[The President] shall take Care that the Laws be faithfully executed ....”).

${ }^{25}$ See Printz v. United States, 521 U.S. 898, 928 (1997) (noting that state officers cannot be "dragooned' . . . into administering federal law" (citation omitted)); New York v. United States, 505 U.S. 144, 175 (1992) (holding that two provisions of a congressional act would “commandeer' state governments into the service of federal regulatory purposes, and would . . . be inconsistent with the Constitution's division of authority between federal and state governments").

${ }^{26}$ See U.S. CONST. art II, $\S 2$ (granting the Executive the power to appoint "Officers of the United States").

27 See, e.g., West Virginia ex rel. Dyer v. Sims, 341 U.S. 22, 24-25, 32 (1951) (granting West Virginia's request for a writ of mandamus ordering the state's treasurer to provide funds to the Ohio River Valley Water Sanitation Commission).

28 The most straightforward issues involve state constitutional law and the dormant Commerce Clause. See infra notes 209, 222, \& 249-252 and accompanying text.

29 United States v. Morrison, 529 U.S. 598, 617-18 (2000).

30 See infra notes 317-319 and accompanying text.

${ }^{31}$ See Petition for a Writ of Certiorari at 21, Kerpen v. Metro. Wash. Airports Auth., 140 S. Ct. 132 (2019) (mem.) (No. 18-1240) (arguing that the authority of a federal-state entity occupies an unconstitutional "delegation twilight zone"). 
jurisprudence, and litigants drawing upon the Court's recent jurisprudence are already questioning whether these entities should even exist. ${ }^{32}$

We conclude, however, that this governance approach is constitutional. While federalism rhetoric often celebrates division, constitutional principles and precedent support-or at least permit-integrative and innovative governance structures. ${ }^{33}$ And while some U.S. Supreme Court holdings, if taken to their extremes, might suggest that a joint agency would face insurmountable problems with delegation, appointment, removal, or commandeering, the U.S. Constitution's text contains no bar on federal-state agencies; taking prior holdings to their extremes does not make sense either as textual interpretation or as structural reasoning. ${ }^{34}$ An enterprising litigant could cobble together a superficially compelling brief filled with statements casting doubt on a joint federal-state agency, but that brief ultimately should fail to persuade.

Our analysis proceeds as follows. Part II sets forth a basic blueprint for a joint federal-state agency and describes how it would operate. Part III explains why such agencies are desirable. It discusses the centrality of federal-state divisions to both constitutional and administrative law, describes traditional responses-both theoretical and practical-to the challenges of dividing authority, and explains how those traditional responses fall short. More generally, Part III explains how recent federalism scholarship, though greatly enamored with overlapping federal and state authority, provides underdeveloped accounts of the doctrines, procedures, and institutional structures that should operate in zones of overlap, and thus shows how our proposal advances a broader theoretical debate. Finally, Part III uses two concrete policy challenges-interstate electric transmission line siting and interstate river management-to illustrate conditions in which joint federal-state governance makes sense and when it is likely to struggle. Part IV then addresses the constitutional

\footnotetext{
32 See, e.g., Kerpen v. Metro. Wash. Airports Auth., 907 F.3d 152, 160-63 (4th Cir. 2018) (examining the constitutionality of the Metropolitan Washington Airport Authority-an independent entity created with the consent of the federal government through an interstate compact), cert. denied, 140 S. Ct. 132 (2019) (mem.).

${ }_{33}$ See infra Section IV.D.

${ }^{34}$ See infra Sections IV.A-IV.C.
} 
questions that existing and new joint, federal-state agencies would likely raise. We conclude that while a joint federal-state agency would likely trigger important constitutional questions, neither constitutional text nor principles should bar its creation. Instead, coequal federalism would honor and advance those constitutional principles.

\section{A BLUEPRINT FOR JOINT FEDERAL-STATE GOVERNANCE}

Before discussing the normative and constitutional contours of joint federal-state governance, a more concrete description of this branch of federalism is in order. Accordingly, this Part summarizes characteristics of this form of governance. It begins with general features before turning to specific features of agency design. While we sometimes use characteristics of existing federalstate agencies as examples, our goal is to explain an idealized structure, not to describe the few joint agencies that already operate.

\section{A. THE GENERAL STRUCTURE OF FEDERAL-STATE GOVERNANCE}

Two key features differentiate joint federal-state governance from dual federalism, cooperative federalism, and systems in which federal and state agencies each independently exercise authority. First, joint federal-state governance does not separate spheres of federal and state responsibility. That contrasts with dual federalism, for which separate spheres are a defining trait. ${ }^{35}$ Even cooperative federalism emphasizes division, though the divisions typically focus on tasks rather than on the subject matter of governance. ${ }^{36}$ For example, under traditional delegated cooperative governance, the federal government often sets national standards-such as national limits on air pollution concentrations-and the states then implement regulatory programs that must meet these standards. ${ }^{37}$ No such division

\footnotetext{
${ }^{35}$ See infra Section III.A.

36 See infra notes 106-110 and accompanying text.

37 See, e.g., 42 U.S.C. $\S \S 7409-10$ (2012) (establishing national air quality standards and requiring states to develop state implementation plans to achieve these standards).
} 
exists in a joint federal-state system, which would unify responsibility within a single agency. ${ }^{38}$

Second, in joint federal-state governance, a single agency exerts binding regulatory authority over the federal government and participating states. For example, in existing water compacts, federal agencies operating in the basin covered by the compact may not spend money on water projects without first having those projects included in the compact commission's plan for the basin. ${ }^{39}$ This contrasts with dual governance schemes, in which states either must accede to federal directives or exercise autonomous control free of federal intervention. ${ }^{40}$ It also contrasts with cooperative federalism systems, in which federal mandates subordinate state decisionmaking. ${ }^{41}$

\section{B. THE MECHANICS OF FEDERAL-STATE GOVERNANCE}

The preceding general description of coequal governance raises many specific questions about how a joint federal-state agency would operate. The discussion below addresses these more specific questions.

1. Participation. Truly joint federal-state governance must take place through a distinct institution, which we assume would be an administrative agency. This agency requires the participation of

38 Additionally, federal-state dialogue in coequal governance would occur within one administrative entity rather than between federal and state entities.

39 See Delaware River Basin Compact, Pub. L. No. 87-328, § 11.1(b), 75 Stat. 688, 701 (1961) ("No expenditure or commitment shall be made for or on account of the construction, acquisition or operation of any project or facility nor shall it be deemed authorized, unless it shall have first been included by the commission in the comprehensive plan ....”). These agencies also have the authority to, and sometimes do, set both water quality standards and implement regulations to achieve these standards. See, e.g., DEL. RIVER BASIN Comm'N, NATURAL GAS DEVELOPMENT REGULATIONS §7.1(a)-(d) (2011), https://www.nj.gov/drbc/ library/documents/naturalgas-REVISEDdraftregs110811.pdf (proposing detailed rules limiting stormwater runoff and other pollution from hydraulically fractured gas well sites within the Delaware River Basin - a proposal later replaced by a resolution to ban hydraulic fracturing within the Basin). For the proposed rule by the Delaware River Basin Commission to ban hydraulic fracturing within the Basin, see Administrative Manual and Special Regulations Regarding Natural Gas Development Activities; Additional Clarifying Amendments, 83 Fed. Reg. 1586, 1586-1591 (proposed Jan. 12, 2018) (to be codified at 18 C.F.R. pt. 401 and 440).

${ }^{40}$ See infra Sections III.A- III.B.

${ }^{41}$ See infra Sections III.C- III.D. 
the federal government and at least one state. That could be the extent of the agency's membership, or it could involve multiple participating states and representatives from multiple federal agencies.

The choice between one state and multiple states likely does not have important constitutional implications, but it may impact the agency's political viability, practical manageability, and efficacy. If an agency has more participating states, the challenges of creating aligned, organic legislation will be greater. Similarly, management may become unwieldy, particularly if each participating state wants representation on the governing board. But an entity that involves more states also may more effectively reach solutions that integrate interests across a broad geographic range.

2. Legislative Creation. All agencies, including joint federalstate agencies, owe their existence to legislation. ${ }^{42}$ Because the federal government cannot command state agency participation in a joint agency, ${ }^{43}$ and the states likewise cannot command the federal government's participation, ${ }^{44}$ a joint federal-state agency's creation would require consistent legislation from each participating government. Either the federal government or the states could use later legislation to withdraw from the agency. ${ }^{45}$

\footnotetext{
${ }^{42}$ See, e.g., City of Arlington v. FCC, 569 U.S. 290, 297 (2013) ("Both [agencies'] power to act and how they are to act are authoritatively prescribed by Congress ....").

${ }^{43}$ See Printz v. United States, 521 U.S. 898, 935 (1997) (holding that federal law cannot commandeer state officials, "or those of their political subdivisions, to administer or enforce a federal regulatory program").

${ }^{44}$ See U.S. ConST. art. VI, cl. 2 (establishing the Constitution to be the "supreme Law of the Land," necessarily subordinating states).

${ }_{45}$ An interesting question is the extent to which the terms of a compact could impose penalties for state withdrawal or provide a withdrawal period. Such terms would limit states' ability to obtain leverage during proceedings by threatening to withdraw or negate undesired orders through immediate withdrawals. Legislative withdrawals from compacts appear somewhat rare. Governor Chris Christie of New Jersey withdrew from the Regional Greenhouse Gas Initiative under a Memorandum of Understanding among the states allowing states to provide thirty days of notice and then withdraw, but New Jersey's legislation and administrative rules implementing RGGI remained on the books. See Julia Ciardullo, New Jersey Governor Announces Withdrawal from RGGI, ColumbIA Climate LAW BLOG (June 3, 2011), http://blogs.law.columbia.edu/climatechange/2011/06/03/newjersey-governor-announces-withdrawal-from-rggi/. Governor Christie also vetoed three subsequent bills that would have required New Jersey's participation in RGGI. See Tom Johnson, Christie Rejects Bill to Rejoin RGGI, for Third (and Last) Time, NJ SpotLight (July 14, 2017), https://www.njspotlight.com/2017/07/17-07-13-christie-rejects-bill-to-rejoinrggi-for-third-and-last-time/.
} 
Existing compact agencies demonstrate multiple ways to create a joint federal-state agency. For example, the federal government could first enact legislation, and states that wish to participate could copy that legislation and enact it as state law. ${ }^{46}$ Some compact agencies have evolved in this way, with the federal government providing pre-approval for compacts aligned with a congressionally enacted template. ${ }^{47}$ Alternatively, a group of participating states could negotiate a compact, enact it through their legislatures, and ask the federal government to enact legislation with similar language. ${ }^{48}$ Finally, bilateral or multilateral negotiations could hammer out the language that all participating legislatures then pass. ${ }^{49}$

For any joint federal-state agency, additional questions would arise regarding the applicability of other federal and state laws not directed at the creation of the agency. Most existing federal and state agencies are bound not just by their organic statutes but also by generally applicable laws (the Administrative Procedure Act ${ }^{50}$ is the most prominent example). The agency's authorizing legislation could resolve many of those questions. Like legislation establishing the authority of wholly federal or wholly state agencies, legislation establishing federal-state agencies could incorporate other statutory requirements or explicitly exempt the agency from those requirements. Courts would then resolve other lingering questions with traditional tools of statutory interpretation.

3. Membership. A joint agency's authorizing legislation also would need to specify the structure of agency leadership. Agencies typically are headed either by a single person ${ }^{51}$ or a multi-member

\footnotetext{
46 See Cuyler v. Adams, 449 U.S. 433, 441 (1981) (“Congress may consent to an interstate compact by authorizing joint state action in advance or by giving expressed or implied approval to an agreement the States have already joined.”).

${ }^{47}$ See, e.g., id. (explaining how the Crime Control Consent Act of 1934 provided this sort of advance authorization).

48 See Note, Charting No Man's Land: Applying Jurisdictional and Choice of Law Doctrines to Interstate Compacts, 111 HARV. L. REV. 1991, 1993 (1998) ("Congress consents to compacts by a statute or a joint resolution, which usually includes the compact's terms.").

${ }^{49}$ See id. ("From colonial times until the 1930 s, parties to a compact usually negotiated through joint commissions.").

505 U.S.C. $\S \S 551-706$ (2018).

51 See, e.g., Leadership, U.S. DEP'T OF ENERGY, https://www.energy.gov/leadership (last visited Oct. 12, 2020) (outlining the Department of Energy's leadership structure, which includes one presiding Secretary).
} 
commission. ${ }^{52}$ While the former approach is used at both federal and state levels, we know of no example of its use for a joint federal-state agency, and likely for good reason: a multi-member commission allows for both federal and state representation within the agency's governing body. ${ }^{53}$ For example, an energy agency involving three states and the federal government might be run by a five-member commission, with each state appointing one commissioner and the federal government appointing two. ${ }^{54}$ The few federal-state agencies that exist tend to have a similar structure, although with less federal involvement; for example, the Delaware River Basin Commission has four state representatives and one federal member, ${ }^{55}$ and the Susquehanna River Basin Commission has three state representatives and one federal member. ${ }^{56}$ Each commission appoints or elects one representative to serve as the commission chair. ${ }^{57}$

No standard formula for choosing the total number of commissioners would be necessary, but odd numbers of commissioners generally avoid the problem of tied votes. ${ }^{58}$ Nor would a standard formula for allocating appointments between federal and state members be necessary. Several factors might

52 See, e.g., Commission Members and Senior Staff, FED. ENERGy REG. CoMmisSION, https://www.ferc.gov/about/commission-members-senior-staff/commission-members-andsenior-staff (last visited Oct. 12, 2020) (describing FERC's twenty-three person membership structure).

53 An agency headed by a single person would raise additional constitutional questions, particularly if the agency head were in any way insulated from presidential termination. See Seila Law L.L.C. v. Consumer Fin. Prot. Bureau, 140 S. Ct. 2183, 2192 (2020) (distinguishing single-head from multi-head agencies and holding that "an independent agency that wields significant executive power and is run by a single individual who cannot be removed by the President unless certain statutory criteria are met" violates the separation of powers).

54 See, e.g., Commissioners, DEL. RIVER BASIN COMMISSION, https://www.nj.gov/drbc/about/commissioners/ (last visited Oct. 12, 2020) (showing a somewhat similar example in which four state governors and one federal representative from the U.S. Army Corps of Engineers make up the commission).

55 See id.

56 See Commissioners, SUSQUEHANNA RIVER BASIN COMMISSION, https://www.srbc.net/about/commissioners/ (last visited Oct. 12, 2020).

57 See id.; Commissioners, DEL. RIVER BASIN COMMISSION, supra note 54.

58 There would be no problem with ties if the agency makes decisions by consensus. An organization that makes consensus-based decisions would raise fewer political objections and constitutional concerns, and its members might have stronger incentives to reach negotiated solutions, but it could also be more vulnerable to impasses. 
inform these choices, such as the extent to which the commission should favor federal or state interests, and the extent to which it should favor particular states. If the commission's jurisdiction includes all of one state but only a small, lightly populated portion of another, equal state representation may be inappropriate. Similarly, the number of federally appointed commissioners could vary depending upon the perceived strength of the national interests before the agency. ${ }^{59}$ The other key consideration is how many commissioners the agency can accommodate while still engaging in deliberative decisionmaking. A large commission may be too unwieldy.

Commissioners could be appointed through a variety of mechanisms. At the federal level, commissioners must be appointed either by the President, by the heads of departments, or by courts. ${ }^{60}$ States may have similar requirements. For example, in interstate compact commissions that control water quantity and quality, state governors serve as members of the commission and appoint alternative commissioners from their respective state environmental agencies. ${ }^{61}$ For agencies involving large numbers of states, alternative mechanisms-perhaps involving state nominations of potential commissioners and then votes by the participating states-might need to substitute for direct appointments to avoid overly large, cumbersome commissions.

The terms and removability of agency heads could be handled in a variety of ways, but our discussion assumes that commissioners would serve for fixed terms unless they are removed by the same entity that initially appointment them.

\footnotetext{
59 Politics would also matter, of course.

60 See U.S. Const. art. II, § 2 ("[The President] shall nominate, and by and with the Advice and Consent of the Senate, shall appoint ... Officers of the United States . . but the Congress may by Law vest the Appointment of such inferior Officers, as they think proper, in the President alone, in the Courts of Law, or in the Heads of Departments."). Appointment by courts or department heads would be lawful only if the commission heads were inferior officers. See Edmond v. United States, 520 U.S. 651, 662-64 (1997) (differentiating between principal and inferior officers); Morrison v. Olson, 487 U.S. 654, 670 (1988) (noting that while principal officers must be appointed by the President alone and confirmed by the Senate, inferior officers may be appointed by the President, the heads of departments, or the judiciary, without Senate approval).

${ }^{61}$ See, e.g., About DRBC, supra note 14 (noting that the governors select "high-ranking officials from their state environmental agencies" to serve as commissioners); Commissioners, DEL. RIVER BASIN COMMISSION, supra note 54 (showing governor members and the alternate commissioners).
} 
4. Staffing and Funding. Agency commissions need support staff, and these positions need funding. Because joint federal-state agencies might replace numerous, disparate, and overlapping preexisting agencies, their staff needs can be substantial. ${ }^{62}$ The staffing of a joint federal-state agency could occur in numerous ways. Costs could be split, or the federal government, as an inducement to state participation, might shoulder most or all of the burden. ${ }^{63}$ In some circumstances, staff already employed by federal or state agencies could also serve the federal-state agency. This already occurs for some compact agencies without federal agency membership. For example, the Interstate Commission for Juveniles, which administers the interstate compact by the same name and addresses child custody and runaway issues across state borders, is primarily comprised of commissioners and staff from each state's relevant juvenile agency. ${ }^{64}$ In other circumstances, the joint agency could have its own dedicated staff.

5. Powers. A typical administrative agency has a variety of powers. It can gather information, either through investigations or by requiring submissions from regulated entities; engage in rulemaking; bring enforcement actions; and adjudicate disputes

62 For example, the Delaware River Basin Commission sought to address redundancies and conflict that arose from "some 43 state agencies, 14 interstate agencies, and 19 federal agencies" that "exercised a multiplicity of splintered powers and duties within the watershed." Clarke D. Rupert, The Delaware River Basin Commission: A Unique Partnership, WATER RESOURCES IMPACT, Sept. 2014, at 3, 3, https://www.state.nj.us/drbc/library/documents/IMPACT-DRBC-Sept2014.pdf. The Commission now has thirty-seven staff positions. See Staff, DEL. RIVER BASIN COMMISSION, https://www.state.nj.us/drbc/about/staff/ (last modified Aug. 18, 2020).

63 For example, the Delaware River Basin Compact's signatory parties pre-committed to support the "current expense budget" of the Commission and to adopt specific budgets that would fulfill their promised amount of contribution. Budget, DEL. RIVER BASIN COMMISSION, https://www.state.nj.us/drbc/about/budget.html (last modified Sept. 16, 2020). They subsequently agreed to a specific percentage apportionment of funds, with the United States committing $20 \%$ and the member states each contributing amounts that ranged from $12.5 \%$ (Delaware) to $25 \%$ (New Jersey and Pennsylvania). Id.

64 See InTERstate COMM’N FOR Juveniles, The InTERSTATE COMPACT FOR JuvenILES 2 , https://www.juvenilecompact.org/sites/default/files/ICJRevisedLanguage.pdf (last revised Aug. 27, 2002) [hereinafter JUVENILE COMPACT] (defining "Compact Administrator" as "the individual in each compacting state . . responsible for the administration and management of the state's supervision and transfer of juveniles"); Texas, INTERSTATE COMMISSION FOR JUVENILES, https://www.juvenilecompact.org/south/texas (last visited Oct. 12, 2020) (showing the Commission's staff as including two probation coordinators from the Texas Juvenile Justice Department). 
brought before it. ${ }^{65}$ A joint federal-state agency need not have all of those powers; its creators might limit its powers to adjudication and investigation, for example, or to gathering and sharing information. But for purposes of discussion, and to present the most constitutionally challenging case, we assume that our joint federal-state agency would hold a full suite of traditional agency powers.

Related to questions about agency powers are questions about the law an agency creates. Specifically, would its rules and orders be considered federal law, state law, or both? For a genuinely joint federal-state agency, we assume that the agency's lawmaking would bind both federal and participating-states' officials as well as private entities, and thus would create both federal and state law.

6. Judicial Review. Judicial review is central to administrative law: it helps ensure agency fidelity to statutory commands and is often cited as a key reason why we willingly accord so much power to bureaucracies. ${ }^{66}$ But judicial review of joint federal-state agency decisions presents a potential conundrum. ${ }^{67}$ The agency's creators must decide whether decisions will be reviewable in state court, federal court, or both. ${ }^{68}$ Our discussion does not assume a specific arrangement; instead, that choice would be subject to negotiation

65 See Lisa Schultz Bressman, Edward L. Rubin \& Kevin M. Stack, The Regulatory STATE 2 (2d ed. 2013) (describing the basic functions of administrative agencies).

66 See, e.g., David S. Tatel, The Administrative Process and the Rule of Environmental Law, 34 HARV. ENV'T L. REV. 1, 2 (2010) ("We tolerate such sweeping [agency] authority only because meaningful judicial review ensures that agency actions are consistent with federal law .....”.

67 See Note, supra note 48, at 1996 (arguing that "[i]nterstate compact agencies, by definition, frustrate . . . categorical treatment").

68 See, e.g., JUVENILE COMPACT, supra note 64, at 13 (designating the U.S. District Court for the District of Columbia or "the Federal District Court where the Interstate Commission's principal office is located" as the place to file for judicial review). It is now black-letter law that "[t]he construction of a compact sanctioned by Congress under Art. I, § 10, cl. 3, of the Constitution presents a federal question," and as a default matter, federal courts hold federal question jurisdiction to hear cases involving interpretation of a compact agency's governing statutes. Petty v. Tennessee-Missouri Bridge Comm’n, 359 U.S. 275, 278 (1959). But Congress could change that default arrangement and assign initial and intermediate review of compact cases to state courts. See Daniel E. Andersen, Note, Straddling the Federal-State Divide: Federal Court Review of Interstate Agency Actions, 101 IOWA L. REV. 1601, 1623 (2016) ("State courts gain jurisdiction when the interstate compact's provisions provide for it."). 
among the legislators who create the agency. Regardless of the choices those legislators make, both federal and state legislators would have to affirmatively consent, in legislation, to judicial review in their chosen forums. ${ }^{69}$ Both the federal government and the states possess sovereign immunity-which no other level of government can abrogate ${ }^{70}$-and would likely be indispensable parties to any lawsuit involving the agency. ${ }^{71}$ Consequently, without state and federal consent, agency decisions could be unreviewable.

Enacting legislation would therefore need to specify the availability of judicial review, the bounds of review, and the proper forum for reviewing agency actions. The legislation could be modeled on the federal Administrative Procedure Act (the APA) or explicitly subject the agency to the APA-and could also incorporate state administrative procedures.

$* * * * *$

Joint federal-state governance need not always take one particular form, nor have we analyzed every possible detail. ${ }^{72}$ Rather, the agency structure explained in this Part provides a basic framework for analyzing the key theoretical and constitutional questions a joint federal-state agency could raise. The next Parts address those questions.

\footnotetext{
69 See Alden v. Maine, 527 U.S. 706, 755-60 (1999) (holding that Congress cannot subject a state to federal-law-based suits in state courts unless the state consents); Seminole Tribe v. Florida, 517 U.S. 44, 72-73 (1996) (holding that Congress cannot subject a state to statelaw-based suits in federal court unless the state consents).

70 But see Seminole Tribe, 517 U.S. at 55-56 (stating that Congress may abrogate a state's immunity if Congress has unequivocally expressed its intent to do so and is acting pursuant to a valid exercise of power).

71 See, e.g., Cty. of San Joaquin v. State Water Res. Control Bd., 63 Cal. Rptr. 2d 277, 284-85 (Cal. Ct. App. 1997) (upholding the dismissal, on indispensable party grounds, of a lawsuit challenging a state agency's regulation of a federal water project).

72 We have not specified how detailed the substantive statutory commands to the agency should be, for example, nor have we explored in detail what standards of review reviewing courts should employ. Further, we have not discussed which set(s) of open government laws, if any, should apply to the joint agency. We hope that our proposal will spur further discussion of the operationalization of federal-state agencies in future work.
} 


\section{A NoRMATIVE JUSTIFICATION FOR JOINT FEDERAL-STATE GOVERNANCE}

Part II explained what joint federal-state governance is, and this Part explains why it is desirable. The core normative justification for this particular brand of federal-state interaction is its ability to address stubborn pathologies that dual federalism and cooperative federalism have yet to conquer. Oversimplifying slightly, those traditional arrangements allocate authority in two primary ways: they either (1) divide and separate authority; or (2) prescribe overlapping and coordinated authority by assigning responsibilities to separate federal and state agencies. This Part analyzes each approach, describes their limitations, and explains why joint governance offers a promising alternative. We do not claim, however, that joint federal-state governance is the fix for all federalism challenges, and we offer criteria for determining when it would be useful.

\section{A. DIVIDE AND SEPARATE}

One venerable understanding of federalism emphasizes divisions of authority. The Constitution's framers, for example, often stated that the federal government would handle matters of national interest while matters of local concern would fall to the states. In The Federalist Papers, James Madison argued that "[t]he federal Constitution forms a happy combination in this respect; the great and aggregate interests being referred to the national, the local and particular to the State legislatures."73 Although the Constitution's language does not clearly mandate strict separations, provisions like the Tenth Amendment are at least consistent with the idea that some governance matters should be divided into separate federal and state spheres. ${ }^{74}$

The modern rhetoric of "dualist federalism," which has tended to predominate in U.S. Supreme Court decisions, also emphasizes

\footnotetext{
${ }^{73}$ The Federalist No. 10, at 69 (James Madison) (Tudor Publishing Co., 1937).

${ }^{74}$ U.S. Const. amend. X ("The powers not delegated to the United States by the Constitution, nor prohibited by it to the States, are reserved to the States respectively, or to the people.").
} 
these separations. ${ }^{75}$ Particularly in Commerce Clause cases, the Court often distinguishes between subject matter governed by the federal government and subject matter governed by the states. ${ }^{76}$ The Court has warned that allowing an overly expansive understanding of commerce would "effectually obliterate the distinction between what is national and what is local and create a completely centralized government." 77 This emphasis on separation sometimes leads the Court to try to carve out distinct subject matter areas in which the federal government should not tread-or at least should not interfere-without Congress first offering a clear statement of its intentions. ${ }^{78}$ Similarly, a key goal of the Court's anti-commandeering decisions has been to preserve the states' ability to operate as separate and distinct political entities. ${ }^{79}$

While the Court's decisions tend to get most of the attention, legislation plays a more significant role in dividing authority between the federal and state governments. Sometimes Congress leaves entire fields, like primary and secondary education ${ }^{80}$ or

75 See Schapiro, supra note 4, at 251, 257-61 (defining dualism as "the view that authority for regulating various subjects must be allocated to the national or state governments" and describing the Court's approach as "dualist").

76 See, e.g., United States v. Morrison, 529 U.S. 598, 617-18 (2000) ("The Constitution requires a distinction between what is truly national and what is truly local").

77 United States v. Lopez, 514 U.S. 549, 557 (1995) (quoting NLRB v. Jones \& Laughlin Steel Corp., 301 U.S. 1, 37 (1937)); see also Morrison, 529 U.S. at 617-18 (emphasizing the need to distinguish between national and local (by which the Court seems to mean state) realms of regulation).

78 See, e.g., Solid Waste Agency v. U.S. Army Corps of Eng'rs, 531 U.S. 159, 174 (2001) (noting "the States' traditional and primary power over land and water use"); Morrison, 529 U.S. at $617-18$ (asserting that some areas are truly local, such as "noneconomic, violent criminal conduct"); Lopez, 514 U.S. at 557 (noting that Congress's power under the Commerce Clause "is subject to outer limits").

79 See Printz v. United States, 521 U.S. 898, 928 (1997) ("It is an essential attribute of the States' retained sovereignty that they remain independent and autonomous within their proper sphere of authority.”); see also U.S. Term Limits, Inc. v. Thornton, 514 U.S. 779, 838 (1995) (Kennedy, J., concurring) ("It was the genius of [the Framers'] idea that our citizens would have two political capacities, one state and one federal, each protected from incursion by the other.").

80 See Kimberly Jenkins Robinson, The High Cost of Education Federalism, 48 WAKE FOREST L. REV. 287, 287 (2013) ("Education federalism in the United States traditionally embraces state and local authority over education and a restricted federal role.”). 
land-use zoning, ${ }^{81}$ primarily to the states, and sometimes it preempts state involvement in broad policy realms. ${ }^{82}$ In many other circumstances, the divisions are more fine-grained. The field of energy law, which we will revisit later in this Part, provides some particularly striking divisions: federal agencies regulate the siting of natural gas pipelines, while states regulate oil pipelines, ${ }^{83}$ and federal agencies regulate wholesale pricing of electricity while states regulate prices for electricity sold at retail. ${ }^{4}$ Similar federal-state divisions recur in many parts of the U.S. Code. ${ }^{85}$

In theory, the reasons for dividing authority are numerous, including, among others, ensuring checks and balances. The Framers viewed the states as competing with the federal government for voters' affections and serving as guard dogs against federal overreach; 86 subsequent federalism accounts frequently cite the benefits that arise from states checking potentially-tyrannical federal authority. ${ }^{87}$ In theory, dividing state

81 See Dave Owen, Urbanization, Water Quality, and the Regulated Landscape, 82 U. CoLO. L. REV. 431, 476-77 (2011) (describing Congressional efforts to distinguish between environmental regulation, which it perceived as appropriate subject matter for federal legislation, and land use planning).

82 See, e.g., Arizona v. United States, 567 U.S. 387, 403, 407, 410 (2012) (finding preemptive federal authority in several subfields of immigration law).

83 See Klass, supra note 10, at 837, 843 (discussing primary jurisdiction for regulating natural gas and oil pipelines).

${ }^{84}$ See Fed. Energy Regulatory Comm'n v. Elec. Power Supply Ass'n, 136 S. Ct. 760, 76667 (2016) (observing that under the Federal Power Act, the states have the authority to regulate the retail sale of electricity).

${ }^{85}$ See, e.g., Cty. of Maui v. Haw. Wildlife Fund, 140 S. Ct. 1462, 1471 (2020) (describing the Clean Water Act's division between federal authority over some forms of surface water pollution and state authority over groundwater pollution and other forms of surface water pollution); James D. Fine \& Dave Owen, Technocracy and Democracy: Conflicts between Models and Participation in Environmental Law and Planning, 56 HASTINGS L.J. 901, 94647 (2005) (describing the Clean Air Act's divisions of authority over mobile-source air pollution).

86 The Federalist No. 17, supra note 73, at 111-13 (Alexander Hamilton) (describing competing affections); THE FEDERALIST NO. 26, supra note 73, at 174 (Alexander Hamilton) (providing what has been described as the guard dogs account, in which vigilant state legislators will warn of and guard against federal overreach); Note, Defending Federalism: Realizing Publius's Vision, 122 HARV. L. REV. 745, 746 (2008) (describing the competing affections and "guard dogs" accounts).

87 See, e.g., RYAN, supra note 7, at 39 ("A primary value associated with American federalism . . . is its architectural promise of checks and balances."); Michael W. McConnell, Federalism: Evaluating the Founders' Design, 54 U. CHI. L. REv. 1484, 1504 (1987) (noting that James Madison acknowledged that the danger of self-interested governance was "best 
and federal power can also address other values, such as ensuring that governance better responds to voter preferences ${ }^{88}$ or that the level of government with the most knowledge of or control over a particular policy issue addresses that issue. ${ }^{89}$ Influential conceptual frameworks like the "matching principle" or the European Union's concept of subsidiarity reflect these latter expectations. The matching principle would assign governance tasks to the smallest government unit whose scale matches the geographic scope of the issue being addressed. ${ }^{90}$ Subsidiarity expresses a similar concept: the central government should avoid addressing issues that member states or localities can competently manage on their own. ${ }^{91}$ A combined government seems at odds with this reasoning, for we routinely assume that one government is the better fit in terms of geographic reach, expertise, and voter representation.

\section{B. THE CHALLENGES OF DIVISION}

These principles are intuitively appealing and explain some of the reasons why federal and state authority are divided. ${ }^{92}$ Nevertheless, for several reasons, they are difficult to put into action.

Most importantly, many governance problems are multi-scalar. They have local, regional, national, and sometimes global

tackled at the state level"); Andrzej Rapaczynski, From Sovereignty to Process: The Jurisprudence of Federalism after Garcia, 1985 SuP. CT. REv. 341, 380 (describing tyrannyprevention as "[p]erhaps the most frequently mentioned function" of federalism).

88 See Michael S. Greve, Real Federalism: Why It Matters, How It Could Happen 3-4 (1999) (emphasizing the importance of competition among governments and arguing that "centralized, uniform rules" are very difficult to tailor to diverse citizen preferences).

89 See Garcia v. San Antonio Metro. Transit Auth., 469 U.S. 528, 576-77 (1985) (Powell, J., dissenting) (arguing that local and state officials better understand local conditions).

90 See Henry N. Butler \& Jonathan R. Macey, Externalities and the Matching Principle: The Case for Reallocating Environmental Regulatory Authority, 14 YALE L. \& POL'Y REV. 23, 53 (1996) ("[R]egulatory authority should go to the political jurisdiction that comes closest to matching the geographic area affected by a particular externality.").

91 See George A. Bermann, Taking Subsidiarity Seriously: Federalism in the European Community and the United States, 94 Colum. L. REV. 331, 334 (1994) ("[T]he Community institutions should refrain from acting . . . if their objectives could effectively be served by action taken at or below the Member State level.”).

${ }^{92}$ See supra notes 83-84 and accompanying text. 
dimensions,${ }^{93}$ and in practice, they require complex interactions among governments at these levels. ${ }^{94}$ That means choosing a single governance level to manage the problem could mean always assigning the problem exclusively to the national government, which would defeat key purposes of federalism. ${ }^{95}$ Alternatively, one could pretend that national interests do not matter and just assign authority to state or local governments without worrying about broader consequences. Sometimes laws do this, but often to the detriment of broader societal interests. ${ }^{96}$

Two additional factors exacerbate this problem. First, the boundaries between public policy problems are not crisp, and a problem that may seem local when defined in one way can become a state or national problem if defined more expansively. ${ }^{97}$ Consider United States v. Morrison, for example: Congress had attempted to frame the issue of violence against women as part of a broader, and economically-significant, anti-discrimination struggle, which aligned the issue with traditional national concerns. ${ }^{98}$ To the Court, however, the prosecution of gendered violence was a classic

${ }_{93}^{93}$ See, e.g., Adelman \& Engel, supra note 18, at 1799 (arguing that the matching principle "assumes away much of the inherent complexity of environmental problems"); William W. Buzbee, Urban Sprawl, Federalism, and the Problem of Institutional Complexity, 68 FoRDHAM L. REV. 57, 63-74 (1999) (describing the multi-scalar nature of problems associated with urban sprawl); Buzbee, Regulatory Commons, supra note 9, at 8-14 (describing situations in which numerous governments have partial authority over multiscalar problems).

94 These interactions are often "horizontal" (collaboration among different governments at one level, such as states working together to address a policy issue), "vertical" (different levels of government, such as federal state actors, working together), and even "diagonal" (different levels of government working together and collaborating horizontally, such as several federal-state or state-local partnerships working together). See Hari M. Osofsky, Diagonal Federalism and Climate Change: Implications for the Obama Administration, 62 ALA. L. REV. 237, 241 (2011) (applying the concepts of "horizontal," "vertical," and "diagonal" interactions to "climate change and clean energy initiatives").

95 See supra Section III.A.

96 See, e.g., Dave Owen, Mapping, Modeling, and the Fragmentation of Environmental Law, 2013 UTAH L. REV. 219, 237 (describing the consequences of allowing local governments to engage in large-lot zoning).

97 See, e.g., Jody Freeman \& Daniel A. Farber, Modular Environmental Regulation, 54 DUKE L.J. 795, 810 (2005) (noting the tendency for "spillover effects" among environmental issues); Waxman, supra note 8, 314-18 (describing the interjurisdictional complexities of national security law).

98 See 529 U.S. 598, 628-34 (2000) (Souter, J., dissenting) (summarizing Congress's findings). 
instance of state criminal law enforcement. ${ }^{99}$ Second, policy problems, and the scales at which they arise, also tend to change over time. For instance, consider the COVID-19 pandemic, in which localized outbreaks quickly became national, and national outbreaks spiraled into a global catastrophe. ${ }^{100}$

Even if assigning a particular geographic scale to each public policy problem were possible, an additional difficulty arises: often, finding a preexisting governance entity that matches that scale may be impossible. In theory, we might adopt a new governance structure for every problem, but that could quickly become unwieldy. ${ }^{101}$ The alternative is to assign problems to preexisting governance units. But policy problems routinely spill across state and local boundaries even if the problems remain subnational in scale. ${ }^{102}$ Consequently, so long as we are committed to generalpurpose subnational governance units with stable boundariessuch as cities, counties, and states-we must accept that those units' boundaries are poor fits for some problems.

Finally, concepts like dual federalism or the matching principle hold uneven traction with the voters and politicians who actually make decisions about allocating authority. State or local governments frequently tackle seemingly global problemsclimate change is a prominent example ${ }^{103}$-and the national government, with strong popular support, asserts authority in

${ }^{99} \mathrm{Id}$. at 618 (majority opinion) ("[W]e can think of no better example of the police power, which the Founders denied the National Government and reposed in the States, than the suppression of violent crime and vindication of its victims.").

100 See Timeline: WHO's COVID-19 Response, World HEALTH ORG., https://www.who.int/emergencies/diseases/novel-coronavirus-2019/interactive-

timeline/\# event-0 (last visited Oct. 12, 2020) (tracing the rise of COVID-19 from a small, localized virus to a global pandemic).

101 See Freeman \& Farber, supra note 97, at 804 (noting the risk of creating "bloated administrative agencies").

102 See, e.g., Buzbee, Regulatory Commons, supra note 9, at 8-14 (providing examples of localized activities with effects that cross local, state, and even national boundaries).

103 See, e.g., Carlson, supra note 18, at 1098-99 (detailing the policy initiatives of state and local governments in response to climate change, despite the federal government's inactivity in this area); Who's In, WE ARE STILL IN, https://www.wearestillin.com/signatories (last visited Oct. 12, 2020) (showing states, local governments, and businesses that have committed to meet the goals of the Paris Agreement-a climate treaty from which President Trump withdrew). 
spheres once associated with state or local governance. ${ }^{104}$ That means divide-and-separate concepts, though appealing when described in academic studies or judicial rhetoric, appear to explain little about the preferences of the people who actually make most decisions about allocating authority.

\section{OVERLAP AND COORDINATE}

Partially because of the problems of the divide-and-separate approach to federalism, American governance is filled with subject areas in which federal, state, and local authority play important roles. Indeed, these zones of overlap are so pervasive that some commentators have dismissed the quest for exclusive authority as a passé sideshow. ${ }^{105}$ American governance institutions have developed an array of systems for working in zones of overlapping authority, and academic theories provide both descriptive accounts of, and normative justifications for, these zones of overlap. ${ }^{106}$

The sheer variety of systems for working on shared issues across federal-state boundaries defies any attempt at a concise summary, but even a partial listing should convey the richness of the field. Some of the more complex regimes use cooperative systems of administrative integration, in which the federal government creates a binding regulatory scheme but allows states to lead the implementation of all or part of that scheme, subject to continuing federal administrative oversight. ${ }^{107}$ In fields ranging

\footnotetext{
104 See, e.g., Engel, supra note 18, at 167 ("The federal government is legendary for poaching on state and local governments' territory by addressing issues that some may argue are purely local."); Richard B. Stewart, Environmental Quality as a National Good in a Federal State, 1997 U. CHI. LEGAL F. 199, 210 (noting that voters tend to perceive environmental issues as national).

105 See, e.g., Heather K. Gerken, Federalism 3.0, 105 CALIF. L. REv. 1695, 1703 (2017) ("Anyone positing state autonomy as federalism's end goal is pursuing a conception of state power that is quickly becoming beside the point in our highly integrated regime.").

106 See, e.g., Buzbee, supra note 6, at 1589 (arguing that floor preemption, in which the federal government sets a minimum standard above which states may regulate, "embraces multilayered institutional arrangements and sets in motion virtually constant federal, state, and private stakeholder interactions"); Freeman \& Farber, supra note 97, at 911 (analyzing the benefits and challenges of involving multiple agencies and multiple levels of governments in addressing environmental problems).

107 See Robert L. Glicksman, From Cooperative to Inoperative Federalism: The Perverse Mutation of Environmental Law and Policy, 41 WAKE FoREST L. REV. 719, 740-41 (2006) (describing cooperative federalism as including both primary federal control with state
} 
from environmental ${ }^{108}$ to health ${ }^{109}$ to telecommunications ${ }^{110}$ law, versions of these systems have assumed central importance. Sometimes as part of these administrative oversight systems, and sometimes outside of them, the federal government often uses its spending power to facilitate coordinated policy in zones of overlapping interest. ${ }^{111}$ When the federal government grants money to states but attaches strings, it can ensure some fealty to national goals while still allowing states discretion to tailor programs to more localized interests. ${ }^{112}$

Other programs navigate overlapping interests by creating obligations for federal regulators (or federally-regulated actors) to consult with, or even seek the approval of, state agencies. ${ }^{113}$ Some of these provisions give states effective vetoes over federal decisions.114 Other provisions create generalized public participation rights that allow states-like any other interested party-to comment on proposed federal decisions, or that require a

implementation and systems that involve federal-state partnerships); Dave Owen, Cooperative Subfederalism, 9 U.C. IRVINE L. REV. 177, 179 (2018) (describing the basic structures of cooperative federalism programs).

108 See Glicksman, supra note 107, at 727-54 (describing the importance and evolution of environmental cooperative federalism programs).

109 See Gluck, Intrastatutory Federalism, supra note 19, at 584 (describing Medicaid and the State Children's Health Insurance Program as "paradigmatic 'cooperative federalism' programs").

110 See Philip J. Weiser, Towards a Constitutional Architecture for Cooperative Federalism, 79 N.C. L. REV. 663, 665-66 (2001) (describing telecommunications regulations as an example of cooperative federalism).

${ }^{111}$ Cf. Erin Ryan, The Spending Power and Environmental Law after Sebelius, 85 U. CoLO. L. REV. 1003, 1012 (2014) ("[T] he spending power enables Congress to bargain with states for access to policymaking arenas that are beyond the reach of its other enumerated powers.").

112 Id. at 1010-12 (describing how Congress uses the spending power to entice states to join regulatory partnerships).

113 See, e.g., 16 U.S.C. § 823a(c) (2018) (requiring the Federal Energy Regulatory Commission (FERC) to consult with states when granting exemptions from hydropower licensing requirements and to include state-recommended conditions in the exemptions); $i d$. $\S 1456(\mathrm{c})(1)(\mathrm{C})$ (requiring federal agencies carrying out activities in coastal areas to certify that their activity is consistent with state coastal zone management policies).

114 See Carlson, supra note 18, at 1100 (describing a system of federalism in which "one level of government-either the singled-out state actor or the national government-moves to regulate a particular environmental policy area" which "then triggers a series of iterations adopted in turn by the higher or lower level of government"). 
federal agency to consult with the states before deciding. ${ }^{115}$ Still others allow federal agencies similar opportunities to comment on states' decisions. ${ }^{116}$ And both state and federal governments regularly litigate when they believe their interests have received insufficient respect. ${ }^{117}$

In addition to these formal mechanisms, states can use politics and informal communications to influence federal decisions, and federal agencies can do the same with the states. State officials (sometimes working through their state's representatives in Congress) routinely use political means to try to influence federal agency decisions. ${ }^{118}$ State and federal agency staff also regularly communicate with each other. ${ }^{119}$ Sometimes those communications involve negotiating authority and policy in zones where authority overlaps and where federal-state dividing lines are blurry. ${ }^{120} \mathrm{Or}$ governments may share expertise and support, either openly or through more clandestine "secret boyfriend" arrangements. ${ }^{121}$ While they receive little public attention and only modest academic interest, these informal federal-state contacts are

115 The classic and most important example is the APA. See 5 U.S.C. § 553(c) (2018) (requiring an opportunity to comment on proposed rules). For consultation, see, for example, 15 U.S.C. $§ 717 b-1$ (b) to -1(c) (2018) (requiring FERC to consult with the state governor regarding potential state and local safety issues associated with a proposed liquefied natural gas terminal, and requiring FERC to "review and respond specifically" to concerns raised).

116 See, e.g., Dave Owen, The Mono Lake Case, the Public Trust Doctrine, and the Administrative State, 45 U.C. DAVIS L. REV. 1099, 1118 (2012) (describing federal agency comments on state water-allocation decisions).

117 See Lin, supra note 21, at 634-46 (describing some of the many recent lawsuits states have filed against the executive branch).

118 See Miriam Seifter, States as Interest Groups in the Administrative Process, 100 VA. L. REV. 953, 955-56 (2014) (describing "how state involvement in federal regulation has been operationalized through a largely overlooked universe of 'state interest groups' ... that lobby federal agencies and consult on pending federal rules and policies, advancing the 'state' view" (footnote omitted)).

119 See Dave Owen, Regional Federal Administration, 63 UCLA L. REV. 58, 107, 114-15 (2016) (describing the frequency of federal-state communications and noting that the geographic distribution of federal offices can facilitate that communication).

${ }^{120}$ See Ryan, supra note 18, at 5 ("Working directly or indirectly with counterparts across state-federal lines, regulators reach consensus about sharing or dividing contested authority . . . in order to move forward with needed governance.”).

${ }^{121}$ Abbe R. Gluck \& Nicole Huberfeld, What Is Federalism in Healthcare For?, 70 STAN. L. REV. 1689, 1767-72 (2018) (describing creative models for Affordable Care Act administration). 
routine, and they provide important mechanisms of coordination in zones of shared interest and authority. ${ }^{122}$

Particularly in recent years, academics have expended great effort in developing theories that integrate the reality of extensive federal-state overlap with the Constitution's emphasis upon treating these two governments as powerful and distinct entities. The emerging theories come with a wide variety of labels, and for purposes of simplicity, we will lump the most prominent groups of ideas into two general (and overlapping) camps. One set of theories generally falls under the label of "interactive" or "dynamic" federalism, ${ }^{123}$ and the other, more recent school describes itself as "nationalist federalism." 124 Both schools of thought agree that dualist federalist theory describes nostalgic ideals, not the complex, overlapping realities of contemporary American governance. ${ }^{125}$ But neither school is willing to write off states, as dual federalism's earlier generations of critics might have done. ${ }^{126}$

122 See Owen, supra note 119, at 114-15 (describing how regional field offices allow federal and state regulators to communicate effectively and "provide geographically limited spaces within which states and local governments can tailor federal policy to their liking").

123 See Blake Hudson, Dynamic Forest Federalism, 71 WASH. \& LEE L. REV. 1643, 165152 (2014) (defining "dynamic federalism"); Hari M. Osofsky \& Hannah J. Wiseman, Dynamic Energy Federalism, 72 MD. L. REV. 773, 809-13 (2013) (summarizing the literature); Schapiro, supra note 4, at 285 ("[T] he key elements of polyphonic federalism are the protection of the institutional integrity of multiple sources of power and the promotion of the dynamic interaction of those centers of authority."). Other articles in this vein have used different terms to describe similar phenomena. See, e.g., Adelman \& Engel, supra note 18, at 1827 (describing "adaptive federalism"); Carlson, supra note 18, at 1099 (describing "iterative federalism" as "repeated, sustained, and dynamic lawmaking efforts involving both levels of government"); Osofsky, supra note 94, at 238 (developing a "diagonal federalism" theory).

124 See, e.g., Gerken, supra note 19, at 1890 (describing a "nationalist school of federalism"); Gluck, supra note 19, at 1998 (describing "National Federalism").

125 See, e.g., Gerken, supra note 105, at 1698 ("A moment's thought should make clear that [separate zones of federal and state sovereignty are not] how the world looks any more. And yet the picture I've just described continues to animate much of constitutional doctrine and theory.").

126 See Cass R. Sunstein, After the Rights Revolution: Reconceiving the REgUlAtoRY STATE 22 (1990) (describing New Deal reformers' view that "[s]tates were weak and ineffectual, unable to deal with serious social problems . . . [and] hardly seemed to be a forum for democratic self-determination"); see also Joel Rogers, Foreword: Federalism Bound, 10 HARV. L. \& POL'Y REV. 281, 282 (2016) (describing concerns about "[b]ad federalism" which "denotes oppressive local elites running riot, or joining with national elites, to resist or undermine civil rights, environmental protection, business standards, or 
Instead, dynamic federalists and nationalist federalists tend to celebrate federal-state overlap, albeit for slightly different reasons.

For the interactive federalists, overlap is desirable primarily because it will lead to better governmental responses to societal problems. ${ }^{127}$ That will happen, theorists explain, partly because overlap creates some redundancy, which means that one level of government can respond to a problem when other levels fail to act. ${ }^{128}$ Additionally, scholars in the interactive federalism camp emphasize that overlap facilitates iterative processes of policy diffusion. ${ }^{129}$ If both federal and state (and local) governments regulate in the same realms, they will be more likely to learn from and build upon each other's initiatives, and successful policies are more likely to traverse the various levels of government, often evolving as they do so. ${ }^{130}$ Overlap, in short, should mean more robust, effective governance. ${ }^{131}$

The nationalist federalists do not disagree with these ideas, but their emphasis is different. Their central priority is maintaining functional politics in a nation marked by profound policy disagreements. ${ }^{132}$ Traditional dual federalists believe that the answer to this dilemma is to carve out discrete policy realms in which states alone could act. ${ }^{133}$ Their solution, in other words, is to provide states with opportunities to exit from national policy

the public goods and social wage other rich countries consider ingredients of a decent society").

127 See, e.g., Adelman \& Engel, supra note 18, at 1832 ("[R]etention of both federal and state jurisdiction reinforces processes that contribute to better regulatory outcomes, particularly opportunities for positive feedback and incentives for a higher level of coordination between the state and federal levels of government.").

128 See Engel, supra note 18, at 178-81 (describing overlapping jurisdictions as a "regulatory safety net"); Erwin Chemerinsky, Empowering States: The Need to Limit Federal Preemption, 33 PePP. L. REv. 69, 74 (2005) ("The genius in having multiple levels of government is that if one fails to act, another can step in to solve the problem.").

129 See, e.g., Carlson, supra note 18, at 1098-1100 (describing the development of federal and state climate policy as an example of iterative federalism).

130 See Engel, supra note 18, at 183 (discussing "vertical policy dissemination" as "the most efficient method of spreading innovation").

131 See id. at 161 (criticizing "static allocation of authority" which "deprives citizens of the benefits of overlapping jurisdiction”); see also Buzbee, supra note 6, at 1599-1612 (arguing against preemption regimes that limit concurrent authority).

132 See supra note 19.

133 See Bulman-Pozen \& Gerken, supra note 19, at 1261 (describing the traditional dual federalists' views). 
schemes, and thus provide consolation prizes when their preferences lose on the national stage. The nationalist federalists agree that states are crucially important, but they have largely rejected this emphasis on exit. ${ }^{134}$ More important, they argue, is a federalism of voice, in which state preferences can be expressed, and conflicts with federal policy can be managed, within zones of overlapping authority. ${ }^{135}$ Overlap, then, is not only-or even primarily-a means for ensuring more robust governance. Instead, it is a framework for managing difficult political conflicts.

\section{THE CHALLENGES OF OVERLAP}

Overlap-and-coordinate approaches are unquestionably central to American federalism, and the theoretical accounts described above help explain their necessity and value. Nevertheless, these approaches can create significant practical problems, and the theoretical responses to these problems remain somewhat thin.

The problems grow from a simple origin: overlapping authority means multiple decision-makers. And while multiple decisionmakers can, and often will, discuss matters and harmonize the processes and substance of their decisionmaking, they will not always make those attempts, and sometimes attempted collaborations will not be fruitful. ${ }^{136}$ One consequence of that failed coordination can be uncertainty about who has authority to issue a decision. ${ }^{137}$ A second consequence can be parallel regulatory processes, which can lead to sequencing challenges, delay, and

\footnotetext{
134 See Heather K. Gerken, Exit, Voice, and Disloyalty, 62 DukE L.J. 1349, 1356 (2013) ("Administrative units are, almost by definition, not sites for exit. They are part of the system, not outside of it.”).

${ }^{135}$ Cf. id. at $1385-86$ ("[W]e have spent relatively little time on the possibility that minorities might make policy rather than complain about it, that they might wield power within the system rather than outside of it, that they might serve as connected critics rather than autonomous outsiders."); see Bulman-Pozen \& Gerken, supra note 19, at 1259 (“[U]ncooperative federalism values a state's voice options over its exit options.").

136 See Freeman \& Rossi, supra note 5, at 1181-96 (describing challenges of coordination and mechanisms to overcome those challenges).

137 See, e.g., Lawrence Susskind \& Ryan Cook, The Cost of Contentiousness: A Status Report on Offshore Wind in the Eastern United States, 33 VA. ENVTL. L.J. 204, 233 (2015) (noting "considerable confusion," which an interagency memorandum later partially resolved, about whether the Bureau of Ocean Energy Management or the FERC held authority to permit offshore wind energy facilities).
} 
potentially conflicting decisions. ${ }^{138}$ Additionally, overlapping authority rarely means equal authority, and one government's decision may trump another's, effectively subordinating interests that the other government was supposed to advance or protect. ${ }^{139}$ Alternatively, the presence of multiple decision-makers can lead to an abdication of authority. ${ }^{140}$ If everyone is responsible, then, effectively, no one is responsible, for every potentially-accountable person can point the proverbial finger at someone else. ${ }^{141}$

These potential problems will be obvious to anyone who has attempted to make a group decision. The key point reduces to the simple cliché that too many cooks will spoil a meal. Nevertheless, the theoretical accounts of federalism that extol the virtues of governmental overlap often gloss over these problems. ${ }^{142}$ They emphasize the positive outcomes that can arise from overlap, and they provide some sampling of the rich variety of ways in which those outcomes emerge. That focus makes some sense; if the goal is to respond to dual federalism's emphasis on separation, then describing the potential virtues of overlapping governance is a good place to start. ${ }^{143}$ But that point has been thoroughly made.

\footnotetext{
138 See, e.g., id. at 216-22 (describing the struggles of the Cape Wind project, which was proposed for Nantucket Sound in Massachusetts).

139 This is a common complaint about federal authority, but it also can arise where federal law hands the trump card to a state. See, e.g., PUD No. 1 of Jefferson Cty. v. Wash. Dep't. of Ecology, 511 U.S. 700, 732-34 (1994) (Thomas, J., dissenting) (discussing the Court's prior warning that granting states "veto power' over federal hydroelectric projects" would improperly limit federal authority (quoting First Iowa Hydro-Elec. Coop. v. Fed. Power Comm'n, 328 U.S. 152, 164 (1946))).

140 See generally Buzbee, Regulatory Commons, supra note 9, at 22-37 (describing regulatory gaps that emerge when numerous governing authorities partially control a regulatory area); Wiseman, supra note 9 , at 242-52 (exploring principal-agent challenges in cooperative federalism).

${ }^{141}$ Buzbee, Regulatory Commons, supra note 9, at 63 ("Where a social ill is juxtaposed against multiple potential regulators, all will be tempted to ignore that social ill and free ride on the anticipated actions of others.").

142 But see Freeman \& Rossi, supra note 5, at 1145-50 (noting, in the context of overlapping jurisdiction among federal agencies, the possibilities of pursuit of "conflicting or incompatible policies," vetoes of one agency's action by another, regulatory gaps, and other collective action challenges).

143 An additional lesson from this literature is that government actors will sometimes forge successful federal-state collaborations where formal governance structures do not support those collaborations or are seemingly designed to inhibit them. See Gluck \& Huberfeld, supra note 121, 1767 (describing a variety of creative forms of healthcare federalism, some without support from state elected officials).
} 
The logical next step is to consider how to manage overlapping governance so that these virtues might be more consistently achieved. Some of that work will focus on existing governance arrangements, which, despite their flaws, have many positive features to recommend them. But some of it may also focus on the possibility of new governance institutions, or on arrangements that have been lurking, largely unnoticed, on the fringes of federalism practice and theory.

\section{E. THE ADVANTAGES OF JOINT GOVERNANCE}

A joint federal-state governance structure may provide a better way of avoiding, or at least limiting, many problems posed by dual and cooperative federalism. To some extent, the benefits of a joint structure invert the disadvantages of separate and overlapping systems. Where divided federalism creates awkward divisions of authority, often giving overlapping responsibility to different levels of government for the same underlying problem, ${ }^{144}$ a joint structure would allow teamwork. Where both dual and cooperative federalism may create the need for serial and potentially conflicting federal and state decisionmaking, a joint agency would allow one-stop shopping, providing the efficiency and clarity of a single, coordinated decisionmaking process. Finally, while dispersing authority among federal and state agencies can create confusion about who is responsible, sometimes leading to the abdication of responsibility, ${ }^{145}$ a joint structure leaves no such doubt. The ultimate result should be more efficient governance.

A joint agency also could better balance federal and state interests. In part, it could provide an effective forum for resolving clashes between federal and state interests and between the interests of different states. Instead of leaving state and federal

\footnotetext{
${ }^{144}$ For example, the Clean Air Act preempts state regulation of mobile sources while also requiring each state to develop an effective regulatory plan for regional air pollutants, which come primarily from the same mobile sources that the state is preempted from regulating. See Fine \& Owen, supra note 85, at 946-47.

145 See Buzbee, Regulatory Commons, supra note 9, at 6-8 (discussing regulatory gaps that emerge from shared partial authority), Justin Weinstein-Tull, Abdication and Federalism, 117 Colum. L. REV. 839, 841 (2017) (describing states' delegation of responsibility to local governments and blame shifting for any inaction to local governments); Wiseman, supra note 9, at 247 (discussing principal-agent issues of cooperative federalism).
} 
agencies to arrive at separate positions and then to use political processes, litigation, or preemption trump cards to sort out the disagreement, a joint agency would provide places and processes where those disagreements must be resolved. That does not mean eliminating conflict, of course; disagreements that once happened between federal and state agencies would instead arise within the agency. Nevertheless, bringing opposing interests together within the same building, rather than leaving them to shout across fences, could lead to substantively better results; repeat interaction and the need to reach a decision could produce more creative outcomes. ${ }^{146}$ Those benefits are particularly likely where the agency combines federal and state staff as well as final decisionmakers. ${ }^{147}$ Even within existing structures, federal and state agency staff can collaborate, but successful working relationships can be easier to forge when the workers commute to the same office and serve on the same team. ${ }^{148}$

Beyond reaching better and more efficient outcomes in individual matters, a joint structure could facilitate better ongoing relationships between federal and state governments. These relationships are, in theory, one of the primary benefits of the overlap-and-coordinate systems of federalism. ${ }^{149}$ Academic accounts of these systems often discuss how overlap can facilitate better learning about policy challenges and sharing of effective responses or can provide more constructive arenas to hash out conflict. 150 But overlap-and-coordinate approaches do not guarantee these benefits. Instead, they will materialize only if agencies pay close attention to what other agencies are doing, which will not always happen if leaders and staff work in separate offices and for separate levels of government. ${ }^{151}$ Policy learning, in

${ }^{146}$ See Owen, supra note 107, at 217-23 (describing the benefits of blurred boundaries and ongoing interaction for state-local governance).

${ }_{147}$ Cf. id. at 219 (noting the successes that local governments have had when both local and state staff communicate consistently).

148 See Owen, supra note 119, at 86-87 (describing arrangements where federal agency staff work out of state agency offices).

${ }^{149}$ See supra notes 118-122 \& 129-130 and accompanying text.

150 See supra notes 127-130 and accompanying text (describing and citing accounts of interactive federalism).

${ }^{151}$ For a discussion of the general challenges of state and local officials figuring out how regulation works in other state and local jurisdictions and how to share information, see Hannah J. Wiseman, Regulatory Islands, 89 N.Y.U. L. REV. 1661, 1694-1723 (2014). 
other words, is not an organic process; it typically requires strong interest and repeat contact, which are easier to achieve when people work together. ${ }^{152}$

Of course, a joint agency structure would also present disadvantages. Political clashes between opposing state and federal interests, as contrasted with heated dialogues among members of a joint commission, might generate a broader array of creative and potentially effective solutions to a problem-although likely with far higher transaction costs and, perhaps, direct harms for the duration of the clash. Forming a joint agency would likely require political will and legislative effort, which may not be forthcoming. A joint agency also would not create a consolidated forum for resolving every potential issue that might arise, for many policy challenges do not map neatly onto the jurisdictions of single agencies, and the need to work with other federal and state agencies would sometimes remain. ${ }^{153}$ Questions would inevitably arise about the boundaries of the agency's responsibility and authority, and about how its powers interact with other state and federal legislative schemes.

Some disadvantages are more subtle. Perhaps most importantly, collaboration between agencies and legislatures would be more challenging with two legislative masters to serve. Agencies are often involved in constructive dialogue with legislatures; agency staff may review and even suggest new legislative initiatives, some of which are enacted, all with the goal of creating more effective regulatory regimes. ${ }^{154}$ That kind of exchange would become more difficult if two legislatures-both state and federal-need to act, particularly when one is the oftengridlocked U.S. Congress. ${ }^{155}$ The resulting challenges could ossify

152 Id. at 1713-22 (describing how a lack of resources and incentives impede information production and sharing between state agencies).

153 See Freeman \& Rossi, supra note 5, at 1136 (observing that "overlapping and fragmented delegations . . . are inevitable, pervasive, and stubborn”).

154 See Christopher J. WALKer, Federal Agencies in the Legislative Process: TECHNICAL ASSISTANCE IN STATUTORY DRAFTING 1-2 (2015), https:/www.acus.gov/sites/ default/files/documents/technical-assistance-final-report.pdf (noting that "federal agencies are involved regularly and extensively in the legislative process").

155 Jody Freeman \& David B. Spence, Old Statutes, New Problems, 163 U. PA. L. REV. 1, 88-93 (2014) (describing and citing to data on congressional polarization and the dysfunction that results). 
the legislative structures within which joint federal-state agencies operate.

These are likely to be significant challenges, and, in some circumstances, they provide reasons why a joint agency would not make sense (or at least be unlikely to emerge). But no governance structure is a panacea, and the key policy question about joint federal agencies instead should be whether they can offer promising alternatives to existing arrangements in some circumstances. Because of their potential benefits for efficiency, finality, and coordination, we believe that they sometimes will.

\section{F. THE CIRCUMSTANCES FOR JOINT GOVERNANCE}

While the primary argument of this Part has been that joint federal-state agencies offer promising alternatives to traditional arrangements, we do not claim that they will always be preferable. This Section, therefore, establishes general criteria for evaluating when a joint federal-state agency will make sense, and it illustrates the potential value of a joint agency under these circumstances through examples drawn from the fields of energy and water management.

Joint federal-state agencies will likely be most effective when several factors converge:

(1) the federal government and states both possess important interests in, and authority over, the subject matter the agency would address;

(2) both levels of government bring important practical advantages to governance, such as knowledge of the governed issue;

(3) states share a policy challenge that they will struggle to resolve independently; and

(4) the agency can address the challenge without opening a Pandora's box of regulatory tasks in divergent jurisdictional areas.

All of these factors need not be present for joint federal-state governance to be preferable to dual or cooperative governance. For example, a single state facing a substantial policy issue could formally team up with federal officials. But the more of these factors present, the more likely it is that joint federal-state 
governance will be appropriate. The two short examples below, which we draw from water and energy law, illustrate how this framework would apply.

1. Siting Transmission Lines for Electricity Generation. A particularly promising opportunity for joint federal-state governance comes from energy law. Among other energy regulation challenges, ${ }^{156}$ joint agencies could help address difficult questions about the siting of new energy transmission lines.

Both federal and state governments have strong interests and traditional authority in this realm. The Federal Power Act gives the federal government control over the interstate transmission and sale of wholesale electricity. ${ }^{157}$ That is a reasonable allocation of control: electricity transmission is a classic example of interstate commerce and has crucial implications for the national economy and the globally significant issue of climate change. ${ }^{158}$ But even though FERC regulates the actual transmission of electricity in interstate commerce, it cannot regulate the location of transmission lines, which are necessary to transport electricity from generators to utilities. ${ }^{159}$ Rather, states exclusively exercise this authority and have regularly blocked important interstate transmission projects. ${ }^{160}$ That may frustrate national goals and the interests of other states, but compelling reasons exist for this state authority. Transmission lines are visually and environmentally

${ }^{156}$ We also think a joint agency would be a good way to address electricity pricing, which is awkwardly divided between federal regulation of wholesale pricing and state regulation of retail pricing. See supra note 84. But that subject is outside the scope of this Article.

157 See 16 U.S.C. § 824(b)(1) (2018) (providing FERC with "jurisdiction over all facilities for [the transmission of electric energy in interstate commerce]"); Fed. Energy Regulatory Comm'n v. Elec. Power Supply Ass'n, 136 S. Ct. 760, 767 (2016) (noting that the Federal Power Act gives FERC the authority to regulate the transmission and sale of electric energy in interstate commerce).

158 See Alexandra B. Klass \& Jim Rossi, Revitalizing Dormant Commerce Clause Review for Interstate Coordination, 100 MINN. L. REV. 129, 143-44 (2015) (describing the importance of transmission infrastructure to renewable energy development).

${ }^{159}$ See Jim Rossi, The Trojan Horse of Electric Power Transmission Line Siting Authority, 39 ENVTL. L. 1015, 1033-36 (2009) (noting a recent congressional attempt to give the federal government some authority over transmission line siting and the courts' narrow construction of the federal statute).

160 See Klass \& Rossi, supra note 158, at 153-54, 190-94 (noting how state laws often block interstate transmission projects). 
intrusive, and states clearly have interests in the siting of major land uses within their territories. ${ }^{161}$

The federal government and states both also have important governance advantages in transmission line siting. Decisions about the location of energy infrastructure-including electric generation plants and transmission and distribution lines-are in some respects rightfully left to the states because of states' historic control over land use decisions and expertise in this area. ${ }^{162}$ And the federal government, which since the 1930s has regulated wholesale electricity, has amassed a great deal of technical knowledge about the process of interstate electricity transmission and about interconnecting generators with that transmission. ${ }^{163}$ Furthermore, the federal government provides an important birdseye perspective on interstate electricity transactions. ${ }^{164}$

Electricity transmission also presents a common policy challenge shared among the states-a challenge that states increasingly struggle to resolve on their own. When electricity first emerged as a consumer service, it was distinctly local; numerous power plants served customers within one city and did not transport energy over long distances. ${ }^{165}$ But over time, generation became increasingly centralized, and power plants began sending electricity over large transmission lines to distant populations. ${ }^{166}$

161 See Anne M. Trainor, Robert I. McDonald \& Joseph Fargione, Energy Sprawl Is the Largest Driver of Land Use Change in United States, PLOS ONE (Sept. 8, 2016), https://doi.org/10.1371/journal.pone.0162269 (evaluating the potential land-based impacts that unconventional energy sources will have on the states).

162 See, e.g., Sara C. Bronin, The Quiet Revolution Revived: Sustainable Design, Land Use Regulation, and the States, 93 MINN. L. REV. 231, 236 (2008) ("For centuries now, land use regulation, administration, and enforcement has centered around localities.").

163 See, e.g., Transmission Planning and Cost Allocation by Transmission Owning and Operating Public Utilities, 136 FERC \ 61,051, at 17-23 (July 21, 2011), https://www.ferc.gov/sites/default/files/2020-06/Order-1000.pdf (describing the Commission's many orders relating to the electricity transmission and the Commission's convening of technical conferences on transmission planning).

164 See Adam Vann, Cong. Research Serv., R40657, The Federal Government's Role

IN EleCtRIC TRANSMission FACILITY Siting 1 (2010),
https://fas.org/sgp/crs/misc/R40657.pdf (discussing calls for an increased federal role in transmission siting because of "concerns over grid congestion and . . reliability").

165 See, e.g., Daniel H. Cole, The "Regulatory Contract," in The End OF A NATURAL Monopoly 43, 73 (Peter Z. Grossman \& Daniel H. Cole eds., 2003) (describing more than forty-five franchises that provided electricity to Chicago residents in 1907).

166 See U.S. DeP'T of EnERgy, United States EleCtricity Industry PRIMER 4 (2015), https://www.energy.gov/sites/prod/files/2015/12/f28/united-states-electricity-industry- 
The modern transmission grid is interstate and even international; much of the grid in the Northeast and Midwest extends into Canada. ${ }^{167}$ Adding to that grid unavoidably requires interstate coordination; a transmission line cannot convey wind energy from Texas to Georgia, for example, without crossing the states in between. But the individual states have limited power to resolve these coordination challenges on their own-and sometimes have strong incentives against doing so. ${ }^{168}$ For example, if Alabama and Tennessee refuse to site the line, Texas and Georgia are stuck.

Finally, although the actual practice of electricity transmission is complex-and is already governed by regional private entities overseen by FERC - the location of new transmission lines is a relatively discrete issue. ${ }^{169}$ Although it is politically contentious, the issue boils down to finding a location for the line that will support new generation and storage, minimally impact individuals who live and operate businesses along the line's proposed route, and connect generation to the areas with the highest electricity demand. ${ }^{170}$ Due to all these factors, state and federal members within a joint federal-state agency might better overcome the existing obstacles to transmission line siting.

2. Interstate Water Quantity and Quality. Interstate water commissions provide a rare, yet living and breathing, example of joint federal-state governance in action. But in contrast to electricity siting, they also provide cautionary stories about circumstances when joint governance will face significant challenges.

primer.pdf (describing the transition from short-distance direct-current transmission of electricity to long-distance alternating-current transmission).

$167 I d$. at 11 (showing the Eastern Interconnection, which covers much of the Midwest, and its extension into Canada).

168 See Klass \& Rossi, supra note 158, at 151 (noting that "each state may not value the benefits of siting the transmission line in the same manner" and that "incentives surrounding the private interest group dynamic can also present the possibility for a state or local government actor to hold out").

169 See Hannah J. Wiseman \& Hari M. Osofsky, Regional Energy Governance and U.S. Carbon Emissions, 43 ECOLOGY L.Q. 143, 184-88 (2016) (describing balancing authorities and regional transmission organizations).

${ }^{170}$ Cf. VANN, supra note 164, at 1 ("State and local governments are well positioned to weigh the local factors that go into siting decisions, including environmental and scenery concerns, zoning issues, development plans, and safety concerns.”). 
These commissions govern the quantity of water withdrawals from interstate rivers and their tributaries; some also regulate the quality of that water. ${ }^{171}$ There are good reasons for joint governance to have emerged in this area. The federal government and states possess strong authority over waterways. Under the equal footing doctrine, states have title to lands beneath waters that were navigable when the states achieved statehood. ${ }^{172}$ States also traditionally exercised primary control over water withdrawals from surface waterways and groundwater aquifers. ${ }^{173}$ Meanwhile, the federal government, under the Commerce Clause, has clear authority to regulate navigable waters. ${ }^{174}$ Both states and federal entities have long histories of exercising these powers, sometimes causing confusion and conflict. As the Delaware River Basin Compact of 1961 notes:

[T]he water resources of the basin are presently subject to the duplicating, overlapping, and uncoordinated administration of some forty-three State agencies, fourteen interstate agencies, and nineteen Federal agencies which exercise a multiplicity of powers and duties resulting in a splintering of authority and responsibilities. ${ }^{175}$

Our second factor-expertise-presents a more complicated story. When Congress and the states created joint agencies to

171 See, e.g., SUSqUeHANNA RIVER BASIN COMM'N, SUSqUEHANNA RIVER BASIN COMPACT 3 (1972), https://www.srbc.net/about/about-us/docs/srbc-compact.pdf (defining "[b]asin" as "the area of drainage of the Susquehanna River and its tributaries into Chesapeake Bay" to a defined point); $i d$. at 10 (providing that Commission approval shall be required for "[a]ny project involving the diversion of water"); id. at 13 (allowing the Commission to set water quality standards for the basin).

172 See Robert W. Adler, The Ancient Mariner of Constitutional Law: The Historical, Yet Declining Role of Navigability, 90 WASH. U. L. REV. 1643, 1658 (2013) (describing the equal footing doctrine).

173 See California v. United States, 438 U.S. 645, 653, 678 (1978) (noting "the consistent thread of purposeful and continued deference to state water law by Congress" and "the need to observe state water law").

174 See, e.g., United States v. Riverside Bayview Homes, Inc., 474 U.S. 121, 133 (1985) (describing Congress's use of Commerce Clause authority to support water quality regulation); United States v. Willow River Power Co., 324 U.S. 499, 509-10 (1945) (holding that federal power to promote navigation trumps state water rights).

175 Delaware River Basin Compact, Pub. L. No. 87-328, 75 Stat. 688, 688 (1961). 
manage river basins, both federal and state governments had expertise in some areas of river management. For example, in addition to its expertise in maintaining navigability, the federal government had long-running (albeit controversial) experience in building and operating dams. ${ }^{176}$ States, meanwhile, held traditional authority over water quality management ${ }^{177}$ and recreational fisheries. ${ }^{178}$ But by any objective measure, the states had been abysmal water quality protectors; responsibility had not yet translated into demonstrated expertise or effectiveness. ${ }^{179}$ And much of the water-management expertise the federal government has since developed-for example, in fields like water quality and endangered species protection-had yet to emerge. ${ }^{180}$ Today, both federal and state water-management expertise is well ahead of what it was in the 1960 s. ${ }^{181}$ But when the joint agencies first emerged and defined their roles, crucial gaps in both federal and state expertise existed. ${ }^{182}$

The third factor (a shared policy challenge) is present in the interstate river context, but the fourth factor (manageably discrete tasks) poses difficulties. Joint federal-state governance will operate most effectively when a joint agency can address a

176 See, e.g., Christine A. Klein, On Dams and Democracy, 78 OR. L. REV. 641, 641-42 (1999) (describing the federally led dam-building effort in the twentieth century).

177 See William L. Andreen, The Evolution of Water Pollution Control in the United States-State, Local, and Federal Efforts, 1789-1972: Part I, 22 STAN. ENVTL. L.J. 145, 17880 (2003) (describing state primacy in water quality regulation in the late nineteenth and early twentieth centuries).

178 See Eric Biber \& Josh Eagle, When Does Legal Flexibility Work in Environmental Law?, 42 ECOLOGY L.Q. 787, 808-09 (2015) (noting traditional state primacy in hunting law, a category in which the authors include fishing regulation).

179 See Andreen, supra note 177, at 178-88 (describing states' struggles to develop water quality standards, collaborate with other states, and address the impacts of industrial pollution)

180 In both fields, a major federal role emerged in the early 1970s, when Congress passed major water quality and endangered species legislation. See Endangered Species Act of 1973, Pub. L. No. 93-205, 87 Stat. 884 (codified at 16 U.S.C. $\S \S ~ 1531-44$ ); Federal Water Pollution Control Act Amendments of 1972, Pub. L. No. 92-500, 86 Stat. 816 (codified as amended at 33 U.S.C. $\S \S 1251-1388)$.

181 See, e.g., Dave Owen, Little Streams and Legal Transformations, 2017 UTAH L. REV. 1, 15-30 (describing the evolution of regulators' understanding of, and approaches to, stream protection).

182 See, e.g., Andreen, supra note 177, at 183-84, 191-94 (explaining the challenges of implementing water quality standards). 
manageable and discrete set of policy issues. ${ }^{183}$ In the context of shared rivers, there is one discrete resource at issue: the river. But the factors that impact rivers, including the amount of water that flows to and through the river and the amount and types of pollution that reach the river, are geographically distributed and incredibly varied. ${ }^{184}$ This gives the federal-state commissions charged with governing these discrete resources a herculean task, often pulling the commissions into politically charged territory as they stray into diverse policy areas. ${ }^{185}$ Here, again, historical contingencies exacerbated the challenges of a sweeping mission. Shortly after the Delaware and Susquehanna River Basin Commissions were created, ${ }^{186}$ Congress enacted a series of statutes that transformed environmental law, inserting much stronger federal governance into realms where the commissions (which federal agencies had never enthusiastically supported) were supposed to act. ${ }^{187}$ Consequently, the agencies had sprawling, illdefined, and contested missions, which they have struggled to fully implement. ${ }^{188}$

Despite these challenges, the river basin commissions live on. But they are rarely cited as model agencies, ${ }^{189}$ and we view them as exemplars of both the challenges and the possibilities of joint federal-state governance.

183 This would not be true where the agency's job is only to generate information and facilitate communication, but not to regulate. Such an agency might provide its greatest value in a messy field where responsibilities are not clearly defined.

184 See, e.g., Del. River Basin Comm'N, State of the BaSin 2019, at 1-2 (2019), https://www.state.nj.us/drbc/library/documents/SOTBreport_july2019.pdf (describing the many influences on the Delaware River).

185 See, e.g., Hari M. Osofsky \& Hannah J. Wiseman, Hybrid Energy Governance, 2014 U. ILL. L. REv. 1, 21-23 (describing the Delaware River Basin Commission's recent and aborted foray into fracking regulation).

186 The Delaware River Basin and Susquehanna River Basin Compacts were introduced in 1961 and 1969, respectively. See DERTHICK, supra note 17, at 46, 73.

187 See id. at 62 (noting that after the passage of the Water Control Act of 1965, the Delaware River Basin Commission "served as a medium for interstate coordination of standards .... [But] the federal and state governments proceeded as if the commission did not exist").

${ }^{188}$ See id at 195-97 (enumerating the various responsibilities of the federal agencies).

189 See, e.g., Bruce A. Ackerman, Susan Rose-Ackerman, James W. SaWyer, JR. \& Dale W. Henderson, The UnCERTain SEARCh For EnVIRONMENTAL Quality 167-68 (1974) (arguing that the Delaware River Basin Commission's structure was dysfunctional). 
These four criteria for joint federal-state governance are likely to be met in a variety of other contexts. For example, although Clean Air Act administration would likely be an unwieldly disaster if performed by a fifty-state federal-state commission, discrete issues within the Act-such as the regional transport of air pollutants-have benefited from governance that somewhat resembles a joint federal-state approach. ${ }^{190}$ And while we have focused on energy and environmental examples because that is where our expertise lies, we suspect many other realms may exist where joint governance holds promise. Healthcare, business and financial regulation, immigration, and other policy arenas might hold intriguing possibilities for joint governance, which we hope policymakers and other researchers will explore.

Nevertheless, as shown by the interstate water commissions, not all situations will be ideal for a formal federal-state approach. And even when this approach does appear promising, it may encounter constitutional challenges. We turn to those challenges in the following Part.

\section{The Constitutionality of JOINT FEDERAL-STATE GOVERNANCE}

The U.S. Constitution is commonly perceived, above all else, as a document mandating separation of powers. ${ }^{191}$ It divides power among the several branches of government and between the federal government and the states. ${ }^{192}$ At the same time, the

\footnotetext{
190 See, e.g., Ozone Transport Commission NOx Budget Program, EPA, https://www.epa.gov/airmarkets/ozone-transport-commission-nox-budget-program (last updated July 19, 2019) (describing the historical multi-state and Environmental Protection Agency (EPA) effort to address the emissions of ground-level ozone-forming air pollutants that move across state borders). The EPA has subsequently issued other ozone transport rules, and the Ozone Transport Commission continues to advise the EPA on ozone transport issues and the need for individual limits on ozone-forming air pollutants within states. See OzOnE TRANSP. COMMISsion, https://otcair.org/ (last visited Oct. 13, 2020) (explaining that the purpose of the Commission is to "advis[e] [the] EPA on transport issues and for developing and implementing regional solutions to the ground-level ozone problem in the Northeast and Mid-Atlantic regions").

191 See supra Section III.A.

192 See supra notes $73-77$ and accompanying text.
} 
Constitution is a document of governmental empowerment. Within their respective spheres, it envisions an energetic executive, a Congress with broad legislative authority, a robust and independent judiciary, and vital and strong states. ${ }^{193} \mathrm{~A}$ joint federal-state agency might seem to complicate these relationships. It combines, rather than separates, federal and state power and does so in relatively novel ways. ${ }^{194}$ In other key respects, it deflects traditional power arrangements. Most importantly, it raises the possibility that the federal government or a state will be bound by a rule or order to which its own representative(s) dissented. ${ }^{195}$

That possibility, and the broader rearrangement of power that a joint federal-state agency accomplishes, likely would raise constitutional questions. Indeed, constitutional issues have often swirled around joint federal-state agencies. In the early 1960s, for example, when states sought federal participation in the Delaware River Basin Commission, the U.S. Department of Justice and Department of the Interior were deeply skeptical of the proposal, partly on constitutional grounds. ${ }^{196}$ The Department of Justice ultimately produced a memorandum tepidly attesting to the proposal's constitutionality, ${ }^{197}$ but only so long as the federal executive branch could reject the commission's positions ${ }^{198}$ - a condition that Congress accepted. ${ }^{199}$ In the 1990s, concerns with

${ }^{193}$ U.S. CONST. art. I-III (vesting legislative, executive, and judicial power within three separate branches); id. amend. X (reserving to the states powers not expressly delegated to the federal government).

194 See supra Section III.E.

195 See infra Section IV.D.2.

196 See DERTHICK, supra note 17, at 49-53 (discussing the constitutional concerns raised by the U.S. Department of Justice and Department of the Interior).

197 Memorandum from Nicholas deB. Katzenbach, Assistant Attorney Gen., Office of Legal Counsel, to the Honorable Frederick G. Dutton, Special Assistant to the President 2 (Apr. 25, 1961) (on file with the John F. Kennedy Presidential Library) ("In our opinion, the Compact does not clearly violate any specific provisions of the Federal Constitution.”).

198 See id. at 14 ("The federal commissioner could not exercise such power over federal regulatory agencies.”).

199 See DERTHICK, supra note 17, at 53 ("The reservation added at the request of the federal executive agencies states that the federal government will not be bound by any provision of the comprehensive plan unless the federal member has concurred in it."). One of Derthick's recurring themes is federal executive ambivalence toward the Commission. E.g., id. at 66 ("[The federal commissioner] is supposed to represent within the commission the interests of a government that has never been convinced that its interests are served by his being there."). 
constitutionality helped forestall the creation of a joint federalstate water regulator in California, again leading to the creation of a weaker agency that was then widely criticized for its ineffectiveness. ${ }^{200}$ More recently, litigants have challenged the constitutionality of the Metropolitan Washington Airports Authority (MWAA), a joint federal-state agency that, according to its opponents, occupies "a delegation twilight zone sheltered from separation-of-powers constraints." 201 The Fourth Circuit rejected those arguments, ${ }^{202}$ and the U.S. Supreme Court denied certiorari. ${ }^{203}$ But similar claims could easily arise again.

In short, while specific constitutional arguments have evolved, some constitutional uncertainty has always accompanied proposals for joint federal-state entities and has rarely been squarely addressed. This Part therefore analyzes constitutional questions that could impede more widespread use of joint federal-state governance. We begin with specific issues before moving to more thematic concerns, explaining why each attack should fail. ${ }^{204}$

While our analysis consists of a series of responses to potential constitutional challenges, an affirmative argument pervades this discussion. Both the Constitution itself and the Framers' other written works anticipate that states and the federal government would interact through a combination of contestation and

\footnotetext{
200 See Freeman \& Farber, supra note 97, at 854 (discussing how "lawyers for both state and federal agencies resisted creating a truly new joint federal-state agency because of concerns about the constitutionality and legality of federal and state entities having a say in each other's activities"). As Freeman and Farber note, the non-regulatory agency that the state and federal governments created did achieve some successes, but it ultimately was unsuccessful in resolving the primary disputes it faced. Id. at 866-76 (discussing the shortcomings of the CalFed Agency).

201 See Petition for a Writ of Certiorari at 21, Kerpen v. Metro. Wash. Airports Auth., 140 S. Ct. 132 (2019) (mem.) (No. 18-1240).

202 Kerpen v. Metro. Wash. Airports Auth., 907 F.3d 152, 160-63 (4th Cir. 2018) (holding that the MWAA does not exercise any extra-constitutional powers).

${ }^{203}$ Kerpen v. Metro. Wash. Airports Auth., 140 S. Ct. 132 (2019) (mem.).

204 Because modes of constitutional analysis are contested, we offer a brief word about the ground rules we will use. The discussion that follows draws on constitutional text and structure, documentary evidence from the period before and after the Constitution's enactment, governing precedent, and broader principles of effective and fair governance. It is, in other words, a somewhat conventional, though obviously contestable, comprehensive approach to constitutional interpretation. See generally Mitchell N. Berman \& Kevin Toh, Pluralistic Nonoriginalism and the Combinability Problem, 91 TEx. L. REV. 1739 (2013) (describing and critiquing interpretive theories).
} 
collaboration. ${ }^{205}$ Much of the academic discussion of federalism, and most of the Court's recent federalism rhetoric, emphasizes the contestation, which leads all too easily to a focus on separation. ${ }^{206}$ But the Framers also wanted successful collaboration, and they understood the importance of robust governance. ${ }^{207}$ The Constitution's text therefore leaves ample room for creative federal-state governance arrangements that correspond to complex and evolving governance needs, ${ }^{208}$ and joint federal-state agencies are one such arrangement.

The following discussion focuses entirely on the U.S. Constitution. That is because a joint federal-state agency requires federal authorizing legislation, and under the Supremacy Clause, that legislation removes any basis for state law objections to such an agency. ${ }^{209}$ That principle was at the heart of the U.S. Supreme Court's decision in West Virginia ex rel. Dyer $v$. Sims, ${ }^{210}$ the one case we are aware of in which a state's participation in a joint federal-state agency was questioned as a potential violation of state constitutional law. Justice Frankfurter (who had earlier written a law review article praising compact agencies ${ }^{211}$ ) rejected that challenge, concluding that federal approval of legislation

205 See infra Section IV.D.1.

206 See supra Section III.A. But see Bulman-Pozen \& Gerken, supra note 19, at 1903-04 (emphasizing the potential for constructive conflict in shared governance regimes).

207 See infra notes 329-333 and accompanying text (noting that the Constitution's structure and the Framers' writings anticipate some intertwinement of federal and state governance).

208 See Aziz Z. Huq, The Negotiated Structural Constitution, 114 CoLUM. L. REV. 1595, 1602-03 (2014) (arguing that the Constitution's flexible terms leave room for negotiation among branches and between levels of government).

209 These principles do not preclude a state from identifying constitutional reasons, or political reasons, for declining to enter a compact. But they do bar a state from arguing that an already-approved compact agency is operating in violation of state law. See West Virginia ex rel. Dyer v. Sims, 341 U.S. 22, 27-32 (1951) (observing that despite West Virginia's interpretation of its laws, "the State has bound itself to control pollution by the more effective means of an agreement with other States" and noting that the state's obligation did not conflict with the state's constitution).

210341 U.S. 22 (1951).

211 See Felix Frankfurter \& James M. Landis, The Compact Clause of the Constitution-A Study in Interstate Adjustments, 34 YALE L.J. 685, 729 (1925) ("The imaginative adaptation of the compact idea should add considerably to resources available to statesmen in the solution of problems presented by the growing interdependence, social and economic, of groups of States forming distinct regions.”). 
forming the agency overrode state-law objections. ${ }^{212}$ In later decisions, federal courts have reduced this analysis to a simple rule: a federally-approved state compact becomes federal law, and once that happens, "it l[ies] beyond the judicial power of any party state to declare the Agreement not binding upon the state, even on state constitutional grounds, ... and its provisions, interpreted as federal law, must prevail over any ... provisions of state law in direct conflict." 213 Consequently, the constitution that matters, for purposes of our discussion, is the federal one. ${ }^{214}$

\section{A. DORMANT COMMERCE CLAUSE}

The dormant Commerce Clause-a doctrine implied from the Commerce Clause-might seem, at first blush, to impede the operations of any joint federal-state agency. The doctrine prohibits states from unduly interfering with Congress's Commerce Clause authority. ${ }^{215}$ More specifically, it requires strict scrutiny review of state actions that discriminate against out-of-state commerce by, for example, placing a higher tax on waste imported from other states. ${ }^{216}$ The doctrine also mandates balancing of state and local

\footnotetext{
212 See Sims, 341 U.S. at 28 ("It requires no elaborate argument to reject the suggestion that an agreement solemnly entered into between States . . . can be unilaterally nullified, or given final meaning by an organ of one of the contracting States. A State cannot be its own ultimate judge in a controversy with a sister State.").

${ }^{213}$ Bush v. Muncy, 659 F.2d 402, 410 (4th Cir. 1981) (first citing Sims, 341 U.S. at 28; then citing Del. River Joint Toll Bridge Comm'n v. Colburn, 310 U.S. 419, 429-30 (1940)).

${ }^{214}$ Conceivably, this might change. The reasoning of Sims contains whiffs of tension with Justice Scalia's concurring opinion in Bond v. United States, which argued that the federal government could not use a treaty to grant itself powers not otherwise provided by the Constitution. 572 U.S 844, 873-76 (2014) (Scalia, J., concurring) (disagreeing with the holding of Missouri v. Holland, 252 U.S. 416 (1920)). By analogy, one might argue that a state cannot use a compact to confer upon itself powers not granted by the state constitution. A compact is different from a treaty because the federal government's Supremacy Clause power has no analogue in international law. Nevertheless, one can imagine an opinion that combines Justice Scalia's rationale in Bond with federalism-based arguments in favor of state autonomy to overrule or limit Sims and related cases. That has not yet happened, and for this discussion we assume that it will not happen.

${ }^{215}$ See Int'l Truck \& Engine Corp. v. Bray, 372 F.3d 717, 724-25 (5th. Cir. 2004) ("The dormant Commerce Clause, also known as the negative Commerce Clause, prohibits states from engaging in economic protectionism.").

216 See Michael E. Smith, State Discriminations Against Interstate Commerce, 74 CALIF. L. REV. 1203, 1236 (1986) (describing the strict scrutiny review and noting that "[n]ot only must the state have a legitimate interest, its regulation must be substantially related to
} 
interests against impediments to commerce when a state policy indirectly affects out-of-state commerce, ${ }^{217}$ and it outright prohibits extraterritorial regulation. ${ }^{218}$ These prohibitions might appear violated if, for example, a joint federal-multistate commission regulates transactions between buyers and sellers in the same state. The problems might seem particularly acute if that state's representatives had voted against the prices or the approval. ${ }^{219}$

A second type of dormant Commerce Clause objection could come from states and private entities outside of the federal-state agency. For example, states that decline to join a federal-state compact to manage a shared river might view the entire compact as discriminatory, giving non-member states less access to water than they might otherwise claim. ${ }^{220}$ Similarly, generators in states outside of a region with a low-carbon energy initiative might claim that market priorities for lower-carbon resources discriminate

that interest"); Or. Waste Sys., Inc. v. Dep't of Envtl. Quality, 511 U.S. 93, 99 (1994) (holding that Oregon's surcharge on waste from other states was facially discriminatory).

217 See Pike v. Bruce Church, Inc., 397 U.S. 137, 142 (1970) ("Where the statute regulates even-handedly to effectuate a legitimate local public interest, and its effects on interstate commerce are only incidental, . . . the extent of the burden that will be tolerated will ... depend on the nature of the local interest involved, and on whether it could be promoted as well with a lesser impact on interstate activities." (citation omitted)).

218 See North Dakota v. Heydinger, 825 F.3d 912, 922 (8th Cir. 2016) (concluding that a Minnesota statute that limited carbon emissions invalidly exercised extraterritorial jurisdiction and would require Congressional approval); Nat'l Solid Wastes Mgmt. Ass'n v. Meyer, 63 F.3d 652, 657 (7th Cir. 1995) (stating that the Court generally strikes down a state statute that "directly regulates or discriminates against interstate commerce").

219 This would be a non-issue if the agency made decisions by consensus.

220 Some have argued that an act that achieved a similar goal violated the dormant Commerce Clause. The federal Water Resources Development Act of 1986 prohibited entities from diverting water away from the Great Lakes without the consent of the governors of all eight states within the Great Lakes basin. See Pub. L. No. 99-662, § 1109, 100 Stat. 4082, 4230 (codified at 42 U.S.C. $§ 1962$ d-20). An attorney for the Council of Great Lakes Governors argued that this prohibition on out-of-region diversions violated the dormant Commerce Clause, noting that although Congress may waive the dormant Commerce Clause, it had not unambiguously done so under the WRDA. See Mark Squillace, Rethinking the Great Lakes Compact, 2006 MicH. ST. L. REV. 1347, 1353 n.51 (describing and critiquing the Lochhead memorandum, which made this argument). 
against their product, which they otherwise could sell in that region. ${ }^{221}$

For a joint federal-state agency, however, existing doctrine holds a ready answer to these potential dormant Commerce Clause claims. That answer comes from (among other cases) a decision better known for its anti-commandeering discussion. In New York $v$. United States, the Court observed that Congress may delegate its Commerce Clause authority to states, and may also allow states to burden interstate commerce, simply through "an expression of [its] "unambiguous intent." 222 Other cases have developed a "coordinated action" theory, concluding that Congress may exercise its interstate commerce authority "in conjunction with coordinated action by the states." ${ }^{223}$ In this sense, when the federal government works with the states to address an issue, it is as if state boundaries have been temporarily erased, and the federal government is sweeping up the willing states in a broader cross-border initiative.

Consequently, if the federal legislation approving a joint federal-state agency demonstrates this unambiguous intent, the agency could proceed without dormant Commerce Clause concerns. $^{224}$ While some scholars have questioned whether Congress can waive an implied constitutional protection such as the dormant Commerce Clause, ${ }^{225}$ that ability remains firmly embedded within U.S. Supreme Court jurisprudence. ${ }^{226}$

221 See, e.g., Heydinger, 825 F.3d at 922 (disapproving a similar state arrangement on grounds of extraterritoriality). But see Energy \& Envtl. Legal Inst. v. Epel, 793 F.3d 1169, 1171 (10th Cir. 2015) (reaching a holding contrary to Heydinger).

222 New York v. United States, 505 U.S. 144, 167, 171 (1992) (quoting Wyoming v. Oklahoma, 502 U.S. 437, 458 (1992)).

223 Prudential Ins. Co. v. Benjamin, 328 U.S. 408, 434 (1946). But see Norman R. Williams, Why Congress May Not "Overrule" the Dormant Commerce Clause, 53 UCLA L. REV. 153, 189-93 (2005) (describing and critiquing Benjamin).

224 See, e.g., RYAN, supra note 7, at 219 (discussing legislative provisions, which New York $v$. United States did not set aside, allowing states that participated in compacts to limit interstate commerce in nuclear waste); see also Erin Ryan, Federalism at the Cathedral: Property Rules, Liability Rules, and Inalienability Rules in Tenth Amendment Infrastructure, 81 U. COLO. L. REV. 1, 31-34 (2010) (describing states' compact approach to nuclear waste).

225 See Williams, supra note 223, at 195 ("[I]t makes no sense from a theoretical perspective to view the Dormant Commerce Clause as existing for the benefit of, and therefore waivable by, Congress."). Williams's concerns might be lessened if the delegation were to an agency involving the federal government, particularly if-as would likely be true 


\section{B. ANTI-COMMANDEERING}

The anti-commandeering doctrine, which arises both from the Tenth Amendment of the Constitution and from broader structural concerns surrounding the division of federal-state authority, might also present problems for joint federal-state agencies. ${ }^{227}$ This doctrine protects state governments from direct federal control. ${ }^{228}$ Accordingly, Congress may not compel or prohibit state legislation, ${ }^{229}$ and it may not force state officials to implement a federal directive. ${ }^{230}$ For example, Congress may not require state and local police to carry out background checks for individuals proposing to purchase guns, as this is an unconstitutional federal "conscript[ion]" of subnational actors to do Congress's bidding. ${ }^{231}$ Nor may Congress force states to pass legislation that takes title to and assumes liability for nuclear waste, ${ }^{232}$ or prohibit state legislation that legalizes sports gambling. ${ }^{233}$

A joint federal-state agency would raise anti-commandeering concerns. The agency would not compel states to legislate, but a joint federal-state agency would issue directives that state regulators would have to implement. Because the agency directive could be characterized as federal-at least one federal member

with energy - the agency would promote interstate commerce. See Klass \& Rossi, supra note 158, at 181-84 (describing Arizona and Missouri's denials of proposed interstate transmission lines and arguing that these could be viewed as dormant Commerce Clause violations).

${ }^{226}$ See Williams, supra note 223, at 194 (acknowledging that the Court allows Congress to waive dormant Commerce Clause restrictions).

227 See RYAN, supra note 7, at 250 (acknowledging the Tenth Amendment and the Constitution's structure as the foundation of the anti-commandeering doctrine).

228 See New York v. United States, 505 U.S. 144, 188 (1992) ("The Federal Government may not compel the States to enact or administer a federal regulatory program.”).

${ }^{229}$ See Murphy v. NCAA, 138 S. Ct. 1461, 1478 (2018) (expanding New York's holding to include a bar against the federal government prohibiting a state from enacting certain legislation).

${ }^{230}$ See Printz v. United States, 521 U.S. 898, 935 (1997) (“The Federal Government may neither issue directives requiring the States to address particular problems, nor command the States' officers ... to administer or enforce a federal regulatory program.”).

${ }^{231} I d$.

${ }^{232}$ New York, 505 U.S. at 188 (holding that the Constitution "does not ... authorize Congress simply to direct the States to provide for the disposal of the radioactive waste generated within their borders").

${ }^{233}$ Murphy, 138 S. Ct. at 1478 (holding that a federal law "prohibiting state authorization of sports gambling-violates the anticommandeering rule"). 
may have voted for it, and it would be binding as federal law-the directive could be viewed as unacceptable commandeering. And a litigant challenging that alleged commandeering would likely rely on some of the broad language from New York $v$. United States, which suggests skepticism of commandeering even when its goal is to solve a collective action problem faced by states. ${ }^{234}$ Prior to New York, states-working through the National Governors' Association-had bargained extensively for federal legislation designed to compel all states to help solve the problem of siting landfills for radioactive waste. ${ }^{235}$ Congress accepted the states' bargain-a deal in which states planned to join a compact-in lieu of enacting legislation that could have preempted the states entirely. ${ }^{236}$ But the U.S. Supreme Court rejected the resulting federal legislation, concluding that "[w]here Congress exceeds its authority relative to the States . . . the departure from the constitutional plan cannot be ratified by the 'consent' of state officials."237

Taken to the extreme, this New York statement would suggest that the states cannot cede authority to a joint federal-state agency even if they wish to do so. But several lines of reasoning prevent this potentially crippling outcome. First, New York itself is readily distinguishable. Though the case arose out of interstate bargaining - through which states indicated that they would form compacts, and forty-two of them ultimately did-New York had not actually approved a compact, and thus the federal legislation at issue was not authorized by the Compact Clause. ${ }^{238}$ For a joint

234 See New York, 505 U.S. at 182 (holding that states "cannot consent" to an otherwise commandeering law).

${ }^{235}$ See id. at 193-94 (White, J., concurring in part and dissenting in part) (outlining the states' actions prior to the adoption of the federal act at issue).

${ }^{236}$ See id. at 195-96 (noting the states' contribution to the federal act at issue).

${ }^{237} I d$. at 182 (majority opinion). See also RYAN, supra note 7, at 250, 253 (discussing the New York holding and describing it as an inalienability rule under the Calabresi-Melamed framework for Coasean bargaining - an entitlement that states may not bargain away even if they wish to); Ilya Somin, Closing the Pandora's Box of Federalism: The Case for Judicial Restriction of Federal Subsidies to State Governments, 90 GEO. L.J. 461, 482 (2002) (describing the anti-commandeering protection of state sovereignty as inalienable).

238 New York, 505 U.S. at 183 ("The fact that the Act, like much federal legislation, embodies a compromise among the States does not elevate the Act (or the antecedent discussions among representatives of the States) to the status of an interstate agreement requiring Congress' approval under the Compact Clause."); see also Ryan, supra note 224, at 32-35 (describing the deal, the legislation, and New York's subsequent actions). 
federal-state agency, in contrast, that Compact Clause authorization would exist. Second, a regulatory scheme that federal legislation compels states to join is profoundly different from a regulatory scheme that states enter and exit at their legislatures' discretion. The latter is not, in any meaningful sense, commandeering the state, even if its day-to-day commands may be binding upon state administrative officials. ${ }^{239}$ Nor is it particularly novel, for even outside of existing federal-state agencies, analogous practices exist. Erin Ryan has extensively discussed states' regular, permissible waivers of their Tenth Amendment authority outside of the anti-commandeering context. ${ }^{240}$ She notes not just that states give up Eleventh Amendment immunity, but also that states regularly waive their authority under the Spending Clause, agreeing to accept federal funds in exchange for weakened autonomy. ${ }^{241}$

Although the anti-commandeering doctrine should not preclude the existence of a joint federal-state agency, the doctrine could limit its structure and operations. Federal legislation could not compel states to participate in the agency, though the federal government could encourage participation by offering it as an alternative to preemption or by offering financial inducements. ${ }^{242}$ Additionally, the federal government could not direct states to appoint or remove particular state members of the governing commission. ${ }^{243}$ But so long as the states control their own participation, they would not be commandeered.

239 Cf. Ryan, supra note 224, at 88 ("[T] [Ne [New York Court's] defense of the Tenth Amendment inalienability rule ... was substantially undermined by dicta implying that even though New York State could not waive its citizens' entitlement to the federal government in negotiating a resolution to the crisis, it might have succeeded in doing so had it joined an interstate compact and waived the same sovereign authority directly to other states.").

240 Id. at 46 (noting that "States routinely waive... their Tenth Amendment sovereign authority to other states in interstate compacts").

${ }^{241}$ Id. ("States routinely waive their Eleventh Amendment entitlement to sovereign authority to private litigants ...."); see also id. at 47 ("[T] he Court's proposition that needed interjurisdictional collaboration can always take place through spending-power negotiations raises the fair question whether the entitlement is really alienable after all.").

${ }^{242}$ See New York, 505 U.S. at 187 (recounting how the federal government used financial incentives to encourage states to participate in a radioactive waste disposal program).

${ }^{243} \mathrm{Cf}$. id. at 188 ("The positions occupied by state officials appear nowhere on the Federal Government's most detailed organizational chart."). 


\section{DELEGATION, APPOINTMENT, AND REMOVAL}

In the form of joint federal-state agency we have proposed, state-appointed actors whose activities are authorized by state and federal law may take actions that bind the federal government. To avoid a commandeering issue, the federal government cannot itself appoint those state actors, nor could it remove them. ${ }^{244}$ That circumstance raises a host of interrelated constitutional issues which can be distilled to a single question: may Congress delegate implementation of federal law to a commission partly composed of state officials who are neither appointed nor removable by the President? ${ }^{245}$ The Court's increasingly formalist ${ }^{246}$ constitutional jurisprudence provides reasons to think the answer is "no." But, as we explain below, delegation to a joint federal-state agency would not violate either constitutional text or principle.

1. Delegation. Under current standards, constitutional delegation doctrine addresses two issues. The first, for which the Court has supplied a clear standard, is what level of guidance must accompany Congress's delegations of authority-so long as those delegations supply an "intelligible principle," which as of this writing remains a capacious concept, the delegation is constitutional. ${ }^{247}$ The muddier question, and the one centrally at issue here, is to whom Congress may delegate authority. Obviously, administrative agencies within the federal executive branch are lawful recipients of delegated authority, but what about a non- or a partially federal entity?

${ }^{244}$ See id.

${ }^{245}$ See Katzenbach, supra note 197, at 12-14 (answering this question in the affirmative).

246 But see Aziz Z. Huq \& Jon D. Michaels, The Cycles of Separation-of-Powers Jurisprudence, 126 YALE L.J. 346, 435 (2016) ("Across a wide variety of doctrinal contexts, the Court cycles between rules and standards, and back again. This cycling cuts across and blends the categories of formalism and functionalism.").

247 Whitman v. Am. Trucking Ass'ns, 531 U.S. 457, 472-75 (2001) (describing the "intelligible principle" standard). In Gundy $v$. United States, four justices (with Justice Kavanaugh not participating) expressed willingness to revisit the delegation doctrine. 139 S. Ct. 2116, 2131 (2019) (Alito, J., concurring) ("If a majority of this Court were willing to reconsider the approach we have taken for the past 84 years, I would support that effort."); id. at 2139 (Gorsuch \& Thomas, JJ., and Roberts, C.J., dissenting) ("This mutated version of the 'intelligible principle' remark has no basis in the original meaning of the Constitution, in history, or even in the decision from which it was plucked."). 
One conceivable answer is that no such delegation is permissible. The Constitution vests executive authority in the President, ${ }^{248}$ and some commentators and justices have suggested that Article II's Vesting Clause prohibits Congressional delegations of executive authority to anyone but the President or subordinates whom the President controls. ${ }^{249}$ As then-Judge Kavanaugh put it (echoing Justice Scalia's famous dissent in Morrison v. Olson ${ }^{250}$ ), Article II requires "not some of the executive power, but all of it" to be vested in the President. ${ }^{251}$ If that is the correct reading, one potential implication is that delegation to a state official is unconstitutional. ${ }^{252}$ Such a prohibition on delegations to non-federal entities has never been adopted by the Court or explicitly endorsed by any of the Justices, but some scholars have warned that it soon could, ${ }^{253}$ or that it should. ${ }^{254}$

248 U.S. Const. art. II, § 1, cl. 1 (“The executive Power shall be vested in a President ....”).

${ }^{249}$ E.g., Steven G. Calabresi \& Saikrishna B. Prakash, The President's Power To Execute the Laws, 104 YALE L.J. 541, 581-82, 595-96 (1994) (arguing that Congress cannot delegate executive powers to entities outside the President's control). In Calabresi and Prakash's view, this principle does not prevent delegations to state officials, but the President must be able to select the delegate, approve or reject their positions, and remove them from authority-which current U.S. Supreme Court precedent would not allow. Id. at 595-97, 639-42. See Printz v. United States, 521 U.S. 898, 933 (1997) (rejecting federal authority to commandeer state officials).

250487 U.S. 654, 697 (1988) (Scalia, J., dissenting).

${ }^{251}$ In re Aiken Cty., 645 F.3d 428, 439 (D.C. Cir. 2011) (Kavanaugh, J., concurring). In his Morrison dissent, Justice Scalia wrote that Article II's vesting clause "does not mean some of the executive power, but all of the executive power." 487 U.S. at 705.

252 See Harold J. Krent, Federal Power, Non-Federal Actors: The Ramifications of Free Enterprise Fund, 79 FordHAM L. REV. 2425, 2426 (2011) ("The recent Supreme Court decision therefore may toll congressional experimentation to vest executive authority in private and state hands.”).

${ }^{253}$ See Ronald J. Krotoszynski, Jr., Cooperative Federalism, the New Formalism, and the Separation of Powers Revisited: Free Enterprise Fund and the Problem of Presidential Oversight of State-Government Officers Enforcing Federal Law, 61 DuKE L.J. 1599, 1610 (2012) (arguing that the Roberts Court is moving toward invalidating "cooperativefederalism programs on the ground that they unconstitutionally delegate the enforcement of federal law outside the executive branch"); Krent, supra note 252, at 2426 (noting that Free Enterprise Fund may restrict Congress's ability "to vest executive authority in ... state hands").

254 See, e.g., Joshua D. Sarnoff, Cooperative Federalism, the Delegation of Federal Power, and the Constitution, 39 ARIZ. L. REV. 205, 211 (1997) ("The Supreme Court should therefore find that delegations to states of overbroad federal regulatory powers violate the Constitution ... to assure that officials imposing federal policies can be held accountable to 
Nevertheless, current practice, historic practice, and textual arguments all suggest that a joint federal-state agency should not raise a difficult delegation issue. In practice, delegations to nonfederal entities abound. Some of those entities are private companies, ${ }^{255}$ some are quasi-public corporate entities, ${ }^{256}$ and some defy simple labeling, ${ }^{257}$ but many of the delegates are state agencies. $^{258}$ Cooperative federalism programs, which pervade American governance, rely heavily on delegations of implementing authority to state agencies. ${ }^{259}$ In most of these programs, federal executive agencies maintain oversight, but that oversight does not translate into complete control. ${ }^{260}$ Additionally, many federal laws confer enforcement authority on state officials, and the Court has rarely questioned those delegations. ${ }^{261}$ Some federal statutes even reverse the traditional hierarchies and make federal agency decisions subservient to state regulators' decisions. ${ }^{262}$ Nor are

all federal citizens and thus will adopt better policies." (footnotes omitted)). Sarnoff does not argue for a categorical ban; instead, he argues for a functional analysis that considers whether the delegation leaves enough federal accountability intact. See id. at 270-80 (outlining a functional approach).

255 See Gillian E. Metzger, Privatization as Delegation, 103 Colum. L. REv. 1367, 1369 (2003) (describing the growing extent of delegations to private entities).

${ }^{256}$ See Anne Joseph O'Connell, Bureaucracy at the Boundary, 162 U. PA. L. REV. 841, 856 (2014) (describing government corporations, such as Amtrak).

${ }^{257} \mathrm{Id}$. at 857-61 (describing several difficult-to-classify entities).

258 See Heather K. Gerken, Slipping the Bonds of Federalism, 128 HARV. L. REV. 85, 116 (2014) (emphasizing the importance of delegated federal power to state governance).

259 See Owen, supra note 107, at 179 (describing how the federal government delegates "program implementation" power to states "[u]nder the classic cooperative federalism model").

260 See Bulman-Pozen \& Gerken, supra note 19, at 1263 (explaining how cooperative federalism schemes provide states with opportunities to "resist" federal power and "empower states to challenge federal authority").

261 See Leah M. Litman, Taking Care of Federal Law, 101 VA. L. REV. 1289, 1308 (2015) (analyzing instances where Congress has "carve[d] out a role for the states in implementing a federal scheme"); Margaret H. Lemos, State Enforcement of Federal Law, 86 N.Y.U. L. REV. 698, 700 (2011) (explaining that Congress can confer enforcement authority to state attorney generals through federal laws that "authorize civil enforcement by . . . the states").

262 See, e.g., 33 U.S.C. $\$ 1341$ (a)(1) (requiring applicants for federal discharge permits to obtain state certifications that the permittees' activities will be consistent with state water quality standards); Arkansas v. Oklahoma, 503 U.S. 91, 103 (1992) (describing Clean Water Act section 401 as "prohibit[ing] the issuance of any federal license or permit over the objection of an affected State unless compliance with the affected State's water quality requirements can be ensured"); California v. United States, 438 U.S. 645, 674 (1978) 
these arrangements new. As Jerry Mashaw has shown, delegations beyond the sometimes-blurry boundaries of the federal government began in the nation's earliest years. ${ }^{263}$ And while some commentators have argued that these arrangements are unconstitutional or have worried that the Court might so hold, ${ }^{264}$ the Court has not yet done so, even though delegations to state agencies have often come before it. ${ }^{265}$

For some constitutional theorists, the pervasiveness of this practice will mean little; present actions, they would argue, shed no light on the meaning of a document drafted centuries ago. ${ }^{266}$ But there are also textual and theoretical reasons why these delegations to non-federal entities should be permissible-albeit with some possible limitations. While one can conceivably interpret the U.S. Constitution's statement that "[t]he executive Power shall be vested in a President of the United States of America," 267 as saying that no one except the President can have authority over the execution of federal law, the terse text falls well short of commanding that interpretation. 268 One alternative reading is that this phrase clarifies that the President-rather than Congress or the courts-will be the entity within the federal government that holds executive authority. ${ }^{269}$ If that is true, then

(holding that the U.S. Bureau of Reclamation must obtain water rights and operate its water projects in compliance with state law).

263 JERRY L. MASHAW, CREATING THE AdMINISTRATIVE CONSTITUTION 298 (2012) (“[F]rom the beginning, coordinate forms of lawmaking and administrative implementation have been a part of our institutional arrangements.").

${ }^{264}$ E.g., Krotoszynski, supra note 253, at 1610 (explaining that the Court may "invalidate cooperative-federalism programs").

265 See, e.g., New York v. United States, 505 U.S. 144, 168 (1992) (affirming the constitutionality of cooperative federalism schemes); see Litman, supra note 261, at 1290 ("[T]he Court has gone out of its way to preserve the states' ability to enforce federal law ....").

266 See Calabresi \& Prakash, supra note 249, at 554 (arguing that "postenactment legislative history" is a poor tool for constitutional interpretation).

267 U.S. CONST. art. II, $\S 1$, cl. 1.

268 See Youngstown Sheet \& Tube Co. v. Sawyer, 343 U.S. 579, 634 (1952) (Jackson, J., concurring) (observing that the Constitution's provisions on executive power are "almost as enigmatic as the dreams Joseph was called upon to interpret for Pharaoh"); Victoria Nourse, Reclaiming the Constitutional Text from Originalism: The Case of Executive Power, 106 CALIF. L. REV. 1, 22-24 (2008) (outlining various interpretations of the Vesting Clause offered by U.S. Supreme Court Justices).

269 Whether the President must hold all of the federal government's executive authority is a subject of vigorous debate. Compare Morrison v. Olson, 487 U.S. 654, 705 (1988) (Scalia, 
the phrase would not address authority vested outside the federal government. That reading is consistent with the expectation, reflected in both the Supremacy Clause and the Founding Fathers' writings, that state actors would give effect to federal law. ${ }^{270}$

In short, a delegation argument against a joint federal-state agency-while arguably consistent with a strongly formalistic constitutional interpretation-is neither mandated by the Constitution's text nor supported by precedent and would mark a radical shift in our governance systems by undercutting state authority in many realms.

2. Appointment. Overlapping concerns might arise with appointment of state members of a joint federal-state agency. The Constitution prescribes appointment of federal officials through just two procedures: principal officers may be appointed only by the President, with the advice and consent of the Senate; and inferior officers may be appointed by the President, the heads of departments, or the courts. ${ }^{271} \mathrm{~A}$ governor is not mentioned, so if the state members of a joint federal-state commission are, in fact, federal officers, then their appointment by a state governor clearly would be unconstitutional. The key question, then, is whether those commissioners are state or federal officers-or both. Although there are arguments for all three classifications, the arguments for treating state appointees as state officers are stronger.

The argument for a federal classification is straightforward: all members of the federal-state agency will participate in a

J., dissenting) (arguing that the President must hold "all of the executive power"), with Youngstown, 343 U.S. at 640-41 (Jackson, J., concurring) (arguing that the Constitution's enumeration of specific executive powers undercuts arguments for a more general executive power), and Robert V. Percival, Presidential Management of the Administrative State: The Not-So-Unitary Executive, 51 DUKE L.J. 963, 967-69 (2001) (arguing that the Constitution's text does not give the President complete authority). Though potentially informed by similar considerations, the question of whether Congress may delegate authority to independent federal agencies differs from the question of whether Congress may delegate authority to a state or joint federal-state agency.

270 See Saikrishna Bangalore Prakash, Field Office Federalism, 79 VA. L. REV. 1957, 1995-2004 (1993) (outlining evidence of this expectation at the founding).

271 U.S. CONST. art. II, § 2 ("[The President] shall nominate, and by and with the Advice and Consent of the Senate, shall appoint Ambassadors, other public Ministers and Consuls, Judges of the supreme Court, and all other Officers of the United States... but the Congress may by Law vest the Appointment of such inferior Officers, as they think proper, in the President alone, in the Courts of Law, or in the Heads of Departments."). 
government entity with three attributes that might make it seem quite "federal." First, the agency will be authorized by the Compact Clause of the U.S. Constitution. ${ }^{272}$ Second, the agency will not exist absent Congressional action. ${ }^{273}$ Third, its decisions will bind federal agencies. ${ }^{274}$ If it walks, talks, and quacks like a federal duck, the argument will go, perhaps that is exactly what it is.

But powerful counterarguments exist. A federal-state entity would also owe its existence to state legislation and would issue decisions that bind state entities, too; it would be a genuinely joint entity. And if the elected branches of federal and state governments choose to create such an entity, and choose to treat its federally- and state-appointed members as representing separate governments, that choice merits some respect. ${ }^{275}$ Additionally, both in practice and in doctrine, we have long accepted a distinction between implementing federal law and being a federal officer. ${ }^{276}$ The state attorney generals (and private plaintiffs) ${ }^{277}$ who enforce federal law $^{278}$ and the state agency officials who implement federally authorized cooperative federalism programs do not lose their state status just because the

272 U.S. Const. art. I, $\S 10$, cl. 3 ("No State shall, without the Consent of Congress ... enter into any agreement or Compact with another State ....").

${ }^{273}$ See supra notes $46-49$ and accompanying text.

274 See supra notes 16, 46-49 and accompanying text (discussing the legal status of compact agencies).

275 See Huq, supra note 208, at 1602 (arguing that judges should respect, and generally not attempt to regulate, power-sharing bargains struck by constitutionally empowered actors).

${ }^{276}$ See Officers of the United States within the Meaning of the Appointments Clause, 31 Op. O.L.C. 73, 99 (2007) ("State officers, even when enforcing federal law, generally exercise the sovereign law enforcement authority of their state, ultimately delegated by the people of that state; if they hold any office, they are officers of their state or locality, not of the United States." (emphasis added)); The Constitutional Separation of Powers between the President and Congress, 20 Op. O.L.C. 124, 145 (1996) (expressing the same principle in different words).

277 See Evan Caminker, The Constitutionality of Qui Tam Actions, 99 YALE L.J. 341, 34143 (1989) (describing qui tam actions, in which a private plaintiff vindicates a broad public interest protected by federal law).

278 See Lemos, supra note 261, at 700 ("Many federal statutes authorize civil enforcement by both a federal agency and the states, typically through states' attorneys general.”). 
law they implement comes from the federal government. ${ }^{279}$ Neither, then, should the state-appointed representatives in a federal-state body lose their ability to function as state officials. ${ }^{280}$

3. Removal. Intertwined with the delegation and appointment questions would be issues about removal. While the Constitution says nothing explicit about removal authority, judges and commentators have long accepted that some presidential authority to remove officials flows from the vesting of executive power in the President and from the Article II directive that the President "take Care that the Laws be faithfully executed." 281 This removal authority, the Court has held, is not absolute; as long as a removal restriction does not limit the President's ability to carry out duties that are "central to the functioning of the Executive Branch," Congress may provide good-cause protection to administrative officials. ${ }^{282}$ But the Court has never sanctioned complete immunity from removal. ${ }^{283}$ Consequently, if the state appointees on a joint federal-state commission are classified as federal officials, the President's complete inability to fire them would likely create an insurmountable constitutional problem. ${ }^{284}$ Some commentators have taken these arguments a step further and suggested that the President might need to have authority to terminate anyone charged with implementing federal law, regardless of the official's classification as federal or state. ${ }^{285}$

279 See Philip J. Weiser, Federal Common Law, Cooperative Federalism, and the Enforcement of the Telecom Act, 76 N.Y.U. L. REV. 1692, 1695-97 (2001) (describing the basic architecture of cooperative federalism programs).

280 See Seattle Master Builders Ass'n. v. Pac. Nw. Elec. Power \& Conservation Planning Council, 786 F.2d 1359, 1364-66 (9th Cir. 1986) (holding that a compact agency's officials need not be appointed by the federal government). The agency in question did not have any federally appointed commissioners. $I d$.

281 U.S. CONST. art. II, § 3.

282 Morrison v. Olson, 487 U.S. 654, 691 (1988).

${ }_{283}$ See, e.g., id. at 696 (noting that the Attorney General may remove independent counsel for "good cause").

284 See Seila Law L.L.C. v. Consumer Fin. Prot. Bureau, 140 S. Ct. 2183, 2192 (2020) (stating that the Court's "precedents have recognized only two exceptions to the President's unrestricted removal power," neither of which would apply in the context of a joint agency).

285 See Krotoszynski, supra note 253, at 1663-68 (discussing various arguments for why the President would need heightened removal power over state actors for a cooperative federalism scheme to be sufficiently effective); Evan Caminker, The Unitary Executive and State Administration of Federal Law, 45 U. KAN. L. REV. 1075, 1091-94 (1997) (elaborating on the methods by which a President could remove state officials administering federal law 
Underlying these textual arguments are broader concerns with the accountability of administrative agencies. "The diffusion of power," the Court has warned, "carries with it a diffusion of accountability." 286 The consequent fear is that executive authority "may slip from the Executive's control, and thus from that of the people." 287 Some Justices have traditionally responded to such fears by arguing that creative governance arrangements respond to the realities of contemporary society, and that the procedural and substantive constraints of administrative law supply ample accountability and oversight. ${ }^{288}$ But the Court's conservatives have expressed growing disdain for arguments grounded in "the era's perceived necessity." 289 That disdain, combined with the willingness of at least some of the conservative justices to drastically limit the scope of administrative governance, ${ }^{290}$ suggests that arguments against joint federal-state agencies may gain traction.

To a large extent, the responses to these potential arguments would echo the responses to arguments about appointment and removal. State appointees on a federal-state commission would be just that-state appointees. ${ }^{291}$ Consequently, if they must be removable by the President, their removability would flow from a principle that all people with significant authority to implement

without violating the Constitution); see also Harold J. Krent, Fragmenting the Unitary Executive: Congressional Delegations of Administrative Authority Outside the Federal Government, 85 Nw. U. L. REV. 62, 69-80 (1990) (discussing congressional delegation of removal power to the President, where state actors are enforcing federal law). None of these articles offer a full-throated endorsement of this position. Krotoszynski and Caminker argue only that it follows from other U.S. Supreme Court decisions. See Krotoszynski, supra note 253, at 1669; Caminker, supra at 1111-12. Krent, though committed to a unitary executive approach, suggests that a countervailing federalism principle could justify delegations to the states. Krent, supra at 110-12.

${ }^{286}$ Free Enter. Fund v. Pub. Co. Accounting Oversight Bd., 561 U.S. 477, 497 (2010).

${ }^{287} I d$. at 499

288 See, e.g., id. at 519-49 (Breyer, J., dissenting) (arguing for and applying a "functional approach," after arguing that no textual provision decides the issue at hand); New York v. United States, 505 U.S. 144, 207 (1992) (White, J., concurring in part) (criticizing the majority for offering a "civics lecture . . a at a time when action, rather than rhetoric, is needed to solve a national problem").

${ }^{289}$ Free Enterprise Fund, 561 U.S. at 501 (quoting New York, 505 U.S. at 187).

290 See, e.g., Dep't of Transp. v. Ass'n of Am. R.Rs., 575 U.S. 43, 70 (2015) (Thomas, J., concurring) (arguing that it is unconstitutional for administrative agencies to create "generally applicable rules of private conduct").

291 See supra note $276 \& 280$ and accompanying text. 
federal law must be subject to removal by the President. ${ }^{292}$ Such a holding would be fatal to not only joint federal-state agencies, but also to cooperative federalism more generally. ${ }^{293}$ The Court has never gone nearly that far, and for good reason. The Take Care Clause is an awfully thin reed upon which to rest such a sweeping holding. It is, after all, just a few ambiguous words, ${ }^{294}$ with passive voice obscuring the identity of the law implementer(s) whose work is to be watched. While perhaps this vague phrase is code for a generalized presidential authority to fire people, the Clause could just as easily be instructing the President to be careful, in some other way, that he follows the laws enacted by Congress. ${ }^{295}$ Indeed, if the Framers had wanted to convey specific rules for removal, there are clearer words they could have used, as the Constitution's Appointments Clause readily illustrates. ${ }^{296}$ Constitutional text, then, provides little basis for a rule prohibiting implementation of federal law by state officials whom the President cannot fire. ${ }^{297}$

Additionally, a crucial distinction exists between a joint federalstate agency and the types of entities that have caused the U.S. Supreme Court to worry about the accountability consequences of

${ }^{292}$ Some scholars have advocated that position. See Calabresi \& Prakash, supra note 249, at 596 (noting the President's exclusive control to execute all federal laws means "all inferior executive officers act in his stead").

293 See Krotoszynski, supra note 253, at 1669 ("If Free Enterprise Fund means what it expressly says, however, cooperative-federalism programs violate the separation-of-powers doctrine by unconstitutionally exporting the execution of federal law to state-government officers.”).

294 See Jack Goldsmith \& John F. Manning, The Protean Take Care Clause, 164 U. PA. L. REV. 1835, 1836, 1838 (2016) (describing the clause's language as "vague but modest," and noting the Court's tendency to use it as a "placeholder for more abstract and generalized reasoning" rather than as language to be interpreted).

295 See Peter L. Strauss, The Place of Agencies in Government: Separation of Powers and the Fourth Branch, 84 CoLuM. L. REV. 573, 649-50 (1984) (noting several ways, other than exercising removal authority, in which the President could "take care" to ensure faithful law implementation); see also Aziz Z. Huq, Removal as a Political Question, 65 STAN. L. REv. 1, 63-66 (2013) (questioning whether removal authority is an effective mechanism of ensuring accountability).

296 See U.S. CONST. art. II, § 2, cl. 2 (providing specific limitations on the President's appointment power).

297 History provides little clarity. As others have noted, the Framers did not discuss removal authority at the Second Constitutional Convention, and for years after the founding, removal authority provoked vigorous debate. See Free Enter. Fund v. Pub. Co. Accounting Oversight Bd., 561 U.S. 477, 517 (2010) (Breyer, J., dissenting) (explaining why history does not "offer significant help"). 
limits on removal authority. ${ }^{298}$ Those concerns have emerged in cases involving an independent agency nested within another independent agency ${ }^{299}$ or in entities that blurred corporate and governmental boundaries. ${ }^{300}$ In those circumstances, no alternative source of elected-executive oversight compensated for the loss of presidential authority. In contrast, in a joint federalstate agency, the commissioners-who are neither appointed nor removable by the President-would be appointed and removable by a governor. An accountability chain linking the agency officials to an executive official-and thus to voters-would remain; the chain would just link to a different executive and a smaller polity. ${ }^{301}$ And while the complexity of the administrative form might still create some voter confusion about authority and responsibility, that complexity is probably less than would exist with a traditional cooperative federalism regime, which the Court has already endorsed as constitutional. ${ }^{302}$ In short, the accountability emphasized in Free Enterprise Fund and analogous cases would remain.

\section{ARGUMENTS FROM CONSTITUTIONAL STRUCTURE AND PURPOSE}

Even if a federal-state agency does not run afoul of some specific constitutional clause or existing precedent, a court might still deem it unconstitutional. Such a holding, if it occurred, would likely be grounded in the idea that broader principles-which are not explicitly stated in any specific clause but nevertheless emerge from the Constitution's structure and history-forbid such a joint

\footnotetext{
298 For a similar argument that "delegations to state entities fundamentally differ from those to private entities" in terms of accountability effects, see Krent, supra note 285, at 2441.

299 Free Enterprise Fund, 561 U.S. at 497 ("If Congress can shelter the bureaucracy behind two layers of good-cause tenure, why not a third?").

300 Dep't of Transp. v. Ass'n of American R.Rs., 575 U.S. 43, 55-56 (2015) (concerning Amtrak).

${ }^{301}$ See Krent, supra note 285, at 2445 ("In contrast to private entities, state officials are politically accountable. They remain subject to the checks and balances in the respective states and can be held to account by the electorate, or at least by their superiors within the state government.").

302 See New York v. United States, 505 U.S. 144, 173-74 (1992) (upholding a cooperative federal-state program).
} 
agency. Despite cogent critique of this sort of extra-textual interpretation, ${ }^{303}$ this interpretative method lies at the core of some of the U.S. Supreme Court's most prominent federalism decisions and will likely recur. ${ }^{304}$ Additionally, even if broader constitutional principles do not lead to a stand-alone claim against a federal-state agency, they would likely inform a court's interpretation of specific clauses and precedents. 305 For these reasons, the discussion below addresses two potential arguments grounded in the Constitution's structure and perceived purposes rather than in any specific clause. It also explains why neither of these arguments should gain traction and why a joint federal-state agency would advance, rather than thwart, constitutional values.

1. Diminishing the States? The first broad-based constitutional argument would assert that a federal-state agency is constitutionally forbidden, or at least dubious, because it would compromise the power of the states. The anticipation of strong states is central to the Constitution; indeed, some modern rhetoric seems to suggest that federalism and state empowerment are interchangeable. ${ }^{306}$ Despite this anticipation, broad subject matter coverage and state dependence upon federal funding and expertise demonstrate the contemporary reality of sweeping federal authority. ${ }^{307}$ Given this pervasive federal authority, a skeptic of coequal federalism might argue that any arrangement that further compromises state independence-even an arrangement into which states willingly enter-is constitutionally dubious.

303 See John F. Manning, Federalism and the Generality Problem in Constitutional Interpretation, 122 HARV. L. REV. 2003, 2008 (2009) ("When judges enforce freestanding 'federalism,' they ignore the . . . bargains and tradeoffs that made their way into the document.").

304 See Thomas B. Colby, Originalism and Structural Argument, 113 Nw. U. L. REV. 1297, 1314 (2019) (providing multiple examples of federalism cases with reasoning largely divorced from specific text).

305 See id. at 1319-22 (describing and critiquing the textual hook approach).

306 See Gil Seinfeld, Neglecting Nationalism, 21 U. PA. J. Const. L. 659, 660 (2019) ("If you ask the average law student—or lawyer, or judge, or legal scholar-for a quick account of what 'federalism' is, you are likely to get 'states' rights' (or something very much like it) as an answer."); Frank B. Cross \& Emerson H. Tiller, The Three Faces of Federalism: An Empirical Assessment of Supreme Court Federalism Jurisprudence, 73 S. CAL. L. REV. 741, 743 (2000) (describing "honest federalism" as "true devotion to states' rights federalism for its own sake").

307 See Gluck, Our [National] Federalism, supra note 19, at 1998-99 (arguing that much of state power now emerges within the domains of federal statutory regimes). 
This argument has a superficial plausibility. We are accustomed to thinking of states as crucial, albeit fragile, partners in our federalist system, 308 of government power as a zero-sum game, ${ }^{309}$ and of the federal government as an ever-expanding behemoth. ${ }^{310}$ Consequently, if the judiciary's task is to keep the delicate state princesses safe from the rampaging federal dragon, keeping the two apart seems like a prudent first step. ${ }^{311}$ That paternalistic approach, however, would have two key flaws.

First, the Constitution is not actually premised on the idea of protecting weak states from a strong federal government. ${ }^{312}$ The document's core purpose was "to form a more perfect Union," 313 which meant, in context, creating a more powerful and effective federal government than had existed under the Articles of Confederation. ${ }^{314}$ Its authors and adopters pursued that goal because they perceived the states as simultaneously enjoying too much authority and remaining perilously vulnerable, with that vulnerability arising because the absence of a strong federal government left the states dangerously exposed to both interstate

308 See, e.g., Gregory v. Ashcroft, 501 U.S. 452, 460 (1991) (warning that the Supremacy Clause gives the federal government "an extraordinary power in a federalist system," which threatens to upset a "delicate balance").

309 See New York v. United States, 505 U.S. 144, 159 (1992) ("As the Federal Government's willingness to exercise power within the confines of the Constitution has grown, the authority of the States has correspondingly diminished to the extent that federal and state policies have conflicted."); Erin Ryan, Negotiating Federalism Past the Zero-Sum Game, 38 ADMIN. \& REG. L. NEWS 4, 4 (2012) (discussing the zero-sum model of federalism).

310 See Free Enter. Fund v. Pub. Co. Accounting Oversight Bd., 561 U.S. 477, 499 (2010) (describing "[t]he growth of the Executive Branch, which now wields vast power and touches almost every aspect of daily life").

311 The Court has made statements suggestive of such a principle, though in different factual contexts. E.g., Printz v. United States, 521 U.S. 898, 928 (1997) ("It is an essential attribute of the States' retained sovereignty that they remain independent and autonomous within their proper sphere of authority.").

312 The Constitution was a delicate compromise between the anti-Federalists, who worried about excessive federal power and argued for strong states' rights, and the Federalists, who supported stronger, centralized authority. See THE FEDERALIST No. 10, supra note 73, at 69 (James Madison) (explaining that the Constitution formed "a happy combination" of national and state interests). For a discussion of the Founders' focus on both national and state interests, see ALISON L. LACroiX, THE IDEOLOGICAL ORIGINS OF AMERICAN FEDERALISM 145-56 (2010).

313 U.S. Const. pmbl.

314 See THE FEDERALIST No. 2, supra note 73, at 16 (John Jay) (noting the importance of "a national government more wisely framed"). 
conflict and foreign manipulation. ${ }^{315}$ A strong federal government was not the only goal, of course; the Framers clearly did not envision a federal government that would completely displace state authority. ${ }^{316}$ They anticipated that the states would remain strong, and they included measures designed to enhance that strength. ${ }^{317}$ But they envisioned state strength emerging partly through the empowerment of a robust federal government; as James Wilson explained, the states' "respectability and power will increase with that of the general government." 318 Indeed, both Madison and Hamilton worried that the states might be a greater threat to the federal government than the federal government to the states. ${ }^{319}$ Equating federalism solely with state empowerment

315 These concerns are central to many of the early Federalist Papers, which focus primarily on the individual states' vulnerability to each other and to foreign manipulation. E.g., The FEderalist No. 3, supra note 73, at 23 (John Jay) (arguing that the federal government can check bordering states' tendency toward war); THE FEDERALIST No. 4, supra note 73 , at 25 (John Jay) (warning that state rivalries could lead to foreign intervention); THE FEDERALIST No. 8, supra note 73, at 49-55 (Alexander Hamilton) (warning again of destructive military rivalries between the states).

316 See Garcia v. San Antonio Metro. Transit Auth., 469 U.S. 528, 568 (1985) (Powell, J., dissenting) ("In our federal system, the States have a major role that cannot be pre-empted by the National Government. As contemporaneous writings and the debates at the ratifying conventions make clear, the States' ratification of the Constitution was predicated on this understanding of federalism.”).

317 See id. at 568-72 (describing the historical background of the Tenth Amendment).

318 James Wilson, Speech, Pennsylvania Convention (Dec. 4, 1787), in FrIENDS OF THE Constitution: Writings of the "OTheR" Federalists 1787-1788, at 240 (Colleen A. Sheehan \& Gary L. McDowell, eds. 1998).

319 See The FeDERALIST No. 21, supra note 73, at 137 (Alexander Hamilton) (warning against "[t]he inordinate pride of State importance"); THE FEDERALIST NO. 33, supra note 73, at 213 (Alexander Hamilton) ("The Convention probably foresaw, what it has been a principle aim of these papers to inculcate, that the danger which most threatens our political welfare is that the State governments will finally sap the foundations of the Union."); THE FEDERALIST No. 45, supra note 73, at 315 (James Madison) ("We have seen, in all the examples of ancient and modern confederacies, the strongest tendency continually betraying itself in the members, to despoil the general government of its authorities, with a very ineffectual capacity in the latter to defend itself against the encroachments."). Hamilton also suggested that the People would be the most important referees of the balance of power between federal and state governments:

[I]t is by far the safest course . . to confine our attention wholly to the nature and extent of the powers as they are delineated in the Constitution. Every thing beyond this must be left to the prudence and firmness of the people; who, as they will hold the scales in their own hands, it is to be hoped, will always take care to 
therefore is distinctly ahistorical; it would turn some of the key principles of the original document on their heads.

The second flaw is that even if state empowerment is a binding constitutional principle, a joint arrangement-even one that involves relinquishing some authority and discretion-can enhance the efficacy of state governance. ${ }^{320}$ Sometimes efficacy will be improved because a partnership will empower the states to address problems they could not otherwise address on their own. ${ }^{321}$ Sometimes it will be enhanced because the pooled expertise of multiple governance entities creates more administrative capacity than any single entity would have by working alone. Both possibilities reflect the broader insight, which is central to contract law, that the ability to enter into mutually binding arrangements is an element of independence and effectiveness, not the enemy of each. ${ }^{322}$ That principle explains why legal systems allow adults but not children to enter into binding contracts, ${ }^{323}$ or why the ability to enter into mutually-binding treaties is a key element of national sovereignty. ${ }^{324}$ Unless we assume that the states are incompetent to resist federal authority and must be protected from federal engagements by a strongly paternalistic constitutional principle, the ability to enter joint federal-state agencies should be a source of state empowerment.

2. Diminishing the People? There is a second, and potentially more compelling, way in which constitutional structure and purpose might be marshalled to oppose a joint federal-state agency. This argument would concede that a joint federal-state

preserve the constitutional equilibrium between the general and the State governments.

The FEDERALIST No. 31, supra note 73, at 204-05 (Alexander Hamilton).

${ }^{320}$ See supra Section III.E (outlining the advantages of joint governance).

321 See supra notes 165-168 and accompanying text.

322 See Richard Craswell, Contract Law, Default Rules, and the Philosophy of Promising, 88 MiCH. L. REV. 489, 514 (1989) (describing contract theories grounded in individual autonomy); see also Daniel Markovits, Contract and Collaboration, 113 YALE L.J. 1417, 1448-49 (2004) (arguing that contracts should be understood as means of constructing relationships and communities).

323 See Markovits, supra note 322, at 1461 n.103 (noting that our unwillingness to accord legal contracting authority to children "indicates a higher legal status" for contracting capacity).

324 See Karl Loewenstein, Sovereignty and International Co-operation, 48 AM. J. INT'L. L. 222, 225 (1954) (“Treaty-making is an act of sovereignty . . .."). 
agency could increase the efficacy of both federal and state governance and then assert that this increased efficacy is exactly the problem. The point of the U.S. Constitution, proponents would argue, is to maintain division and jealous competition between federal and state governments, and thus to empower the people. And if government unifies and grows stronger, the argument would suggest that the people grow correspondingly weaker, a result the Constitution implicitly forbids. Indeed, one might worry that when states and the federal government formally collude through a combined agency, the power of the government vis-à-vis individuals would be at its peak, and no state competition could quell this power. ${ }^{325}$

Modern U.S. Supreme Court opinions would provide no shortage of fodder for this argument. ${ }^{326}$ A passage from Gregory $v$. Ashcroft ${ }^{327}$ illustrates this separate-to-empower idea, as well as its roots in the writings of Alexander Hamilton and James Madison:

Perhaps the principal benefit of the federalist system is a check on abuses of government power. "The 'constitutionally mandated balance of power' between the States and the Federal Government was adopted by the Framers to ensure the protection of "our fundamental liberties." ... [A] healthy balance of power between the States and the Federal Government will reduce the risk of tyranny and abuse from either front. Alexander Hamilton explained to the people of New York, perhaps optimistically, that the

\footnotetext{
325 See GREVE, supra note 88, at 11 (arguing that the Founders focused on "the welfare and liberty of individual citizens" and that modern federalism, which allows for competition among the states, fosters this welfare and liberty).

326 See, e.g., Nat'l Fed'n. of Indep. Bus. v. Sebelius, 567 U.S. 519, 536 (2012) ("State sovereignty is not just an end in itself: Rather, federalism secures to citizens the liberties that derive from the diffusion of sovereign power." (quoting New York v. United States, 505 U.S. 144, 181 (1992)); Printz v. United States, 521 U.S. 898, 921 (1997) ("This separation of the two spheres is one of the Constitution's structural protections of liberty."); United States v. Lopez, 514 U.S. 549, 552 (1995) (emphasizing the importance of division to the protection of liberty); Garcia v. San Antonio Metro. Transit Auth., 469 U.S. 528, 571-72 (1985) (Powell, J., dissenting) (emphasizing the states' role as "counterpoise" to federal power, and asserting that the "constitutionally mandated balance of power between the States and the Federal Government" is "designed to protect our fundamental liberties").

327501 U.S. 452 (1991).
} 
new federalist system would suppress completely "the attempts of the government to establish a tyranny":

"[I]n a confederacy the people, without exaggeration, may be said to be entirely the masters of their own fate. Power being almost always the rival of power, the general government will at all times stand ready to check the usurpations of the state governments, and these will have the same disposition towards the general government. The people, by throwing themselves into either scale, will infallibly make it preponderate. If their rights are invaded by either, they can make use of the other as the instrument of redress." 328

Under this reasoning, a genuinely joint federal-state agency might well be a bridge too far. But there are problems with treating this argument as a binding constitutional principle rather than just as a background concern.

The first problem is that opposing principles also emerge from both the constitutional text and surrounding rhetoric. The Framers clearly wanted to maintain the people's sovereignty over the government, but they also wanted a robust government; they repeatedly noted that a government that struggles in its administration would be of service to no one. ${ }^{329}$ As Hamilton explained, "I am much mistaken, if experience has not wrought a deep and solemn conviction in the public mind, that greater energy of government is essential to the welfare and prosperity of the community." 330 They also planned for many ways, including the creation of the Electoral College and the provisions for state appointment of senators, in which federal and state governance would be intertwined. ${ }^{331}$ While the Constitution itself does not

328 Id. at 458-59 (second alteration in original) (first quoting Atascadero State Hosp. v. Scanlon, 478 U.S. 234, 242 (1985); then quoting THE FEDERALIST No. 28, at 180-81 (Alexander Hamilton) (Clinton Rossiter ed., 1961)).

329 The FEDERALIST No. 23, supra note 73, at 155 (Alexander Hamilton) ("Not to confer in each case a degree of power commensurate to the end, would be to violate the most obvious rules of prudence and propriety, and improvidently to trust the great interests of the nation to hands which are disabled from managing them with vigor and success.”).

330 THE FEDERALIST No. 26, supra note 73, at 171 (Alexander Hamilton).

331 See U.S. ConsT. art. I, § 3 (providing for state legislatures to choose Senators); Matthew J. Festa, Note, The Origins and Constitutionality of State Unit Voting in the 
speak of joint federal and state administration of the laws, ${ }^{332}$ some of the Framers' writings anticipate joint administration taking place, particularly with respect to tax collection. ${ }^{333}$ These clauses and writings suggest that the Framers anticipated that states and the federal government would interact as both collaborators and rivals, not exclusively as one or the other. Equally important, the Constitution contains no provision forbidding joint federal and state administration of the laws, though clearly it could have done so.

Additionally, creating a joint entity would not unify federal and state governance into a harmonious whole. State-appointed agency officials still would advocate and vote for state-supported positions, and federal officials would do the same, as both would be appointed and subject to removal by their respective political leaders. ${ }^{334}$ In all likelihood, the commissioners' disagreements would be memorialized in written dissents, increasing the transparency of conflicts. ${ }^{335}$ In some matters, strong disagreement among the state and federal members of the agencies would lead to gridlock and leave no majority vote winner. Furthermore, because state and federal participation within these agencies would be entirely voluntary, states could simply exit the regime as the ultimate expression of their dissent. ${ }^{336}$ Just as cooperative

Electoral College, 54 VAND. L. REV. 2099, 2113-19 (2001) (describing the origins of the Electoral College). The Seventeenth Amendment replaced legislative appointment with popular elections, but that later action does not change the basic point that the Framers were not attached to a principle of strict federal-state separation. See U.S. ConsT. amend. XVII.

332 Many commentators have noted that the Constitution says little at all about administration. See, e.g., MASHAW, supra note 263, at 12-13 (citing earlier treatises that made this observation).

333 See, e.g., The Federalist No. 36, supra note 73, at 233-34 (Alexander Hamilton) (noting that the national legislature can make use of the "system of each State within that State” to collect taxes); see Printz v. United States, 521 U.S. 898, 945-47 (1997) (Stevens, J., dissenting) (summarizing these writings).

${ }^{334}$ See supra notes $242-244$ and accompanying text.

335 See Sharon B. Jacobs, Administrative Dissents, 59 WM. \& MARY L. REV. 541, 612-13 (2017) (noting that separate opinions offer a unique glimpse into commission decisionmaking and commissioner preferences).

${ }^{336}$ For example, New Jersey withdrew from the Regional Greenhouse Gas Initiativewhich lacks a federal representative, but otherwise resembles a federal-state agency-when that state's politics turned more conservative, although the state later re-joined the initiative. See H.J. Mai, New Jersey Adopts Rules to Rejoin RGGI, Heading to $100 \%$ Clean 
federalism sometimes provides a clearly-defined forum for federalstate conflict, so too would a joint federal-state agency often provide a forum for intergovernmental contestation. ${ }^{337}$ And the people of the nation and the states, through their elected representatives, would still retain authority over the joint enterprise, as well as the option to urge their leaders to leave it entirely. ${ }^{338}$

In summary, a joint federal-state agency should be constitutional, although not every defense explored here would be a sure win. One could (as some litigants have done) easily manufacture an argument from some Justices' unitary executive, federalism, and anti-administrative rhetoric that joining federal and state power in a single entity is unconstitutional. ${ }^{339}$ But once one moves past the rhetorical flourishes and examines constitutional text, the structure of the document, the intentions of the Framers, and judicial precedent, it becomes apparent that nothing in the Constitution forbids such an arrangement. And while some of the Court's contemporary jurisprudence reflects a deep unease with novel and creative administrative arrangements, ${ }^{340}$ the sort of innovation we describe here reflects the spirit of the Constitution itself. The document was designed to produce a thriving nation through the combined, and sometimes innovative, efforts of federal and state governments. It reflects, in James Madison's words, the "manly spirit" that, while not opposed to "decent regard to the opinions of former times and other nations," prevented the American people from allowing "a blind veneration for antiquity, for custom, or for names, to overrule the suggestions of their own good sense, the knowledge of their own situation, and the lessons of their own experience." 341 The Constitution thus empowers the political branches of federal and state government to do more with joint federal-state agencies.

\footnotetext{
Energy by 2050, UTILITY DIVE (June 18, 2019), https://www.utilitydive.com/news/newjersey-adopts-rules-to-rejoin-rggi-heading-to-100-clean-energy-by-205/557078/.

337 See generally Bulman-Pozen \& Gerken, supra note 19 (describing the frequency of conflict within cooperative federalism regimes).

${ }^{338}$ See supra note 45 and accompanying text.

339 See supra notes 237, 251, 289-290 and accompanying text.

340 See Gillian E. Metzger, 1930s Redux: The Administrative State Under Siege, 131 HARV. L. REV. 1, 19 (2017) (noting recent cases demonstrating skepticism towards "administratively novel arrangements").

${ }^{341}$ The Federalist No. 14, supra note 73, at 94 (James Madison).
} 


\section{CONCLUSION}

For years, federalism debates have pitted advocates of separation against advocates of overlap. While the advocates of separation can find ample support in U.S. Supreme Court rhetoric and have gained some traction in the Court's holdings, the overlap advocates make a persuasive case that cooperation is both an inevitable and often positive feature of our governance systems. But their persuasive arguments raise a host of additional issues, all centering on two basic questions. First, how can a federalist system structure overlap to produce successful and efficient governance rather than a duplicative, conflict-ridden mess? Second, even if a proposed structure makes sense as policy, would it be constitutional?

This Article has proposed an innovative answer to these questions. A joint federal-state agency would avoid some of the divided decisionmaking problems that plague dual federalist structures. It also would avoid some of the issues of multi-state coordination and multi-layered delegation that affect cooperative federalism regimes. More generally, it would provide a forum for federal-state and multi-state dialogue. And, as we have explained, it would be constitutional. We do not argue that joint agencies would solve all problems of governance structure in a federalist system; no governance structure can fulfill that tall order. But joint agencies' potential justifies more extensive use. 